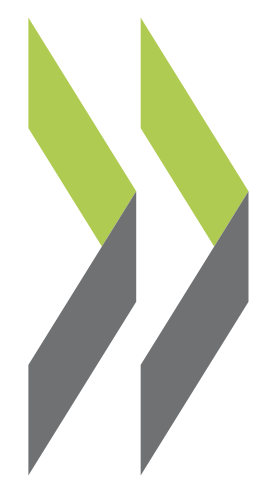

OECD Economics Department Working Papers No. 884

How Institutions Shape the Distributive Impact of Macroeconomic Shocks: A DSGE Analysis
Rudiger Ahrend,

Charlotte Moeser,

Tommaso Monacelli 
Organisation de Coopération et de Développement Économiques

Organisation for Economic Co-operation and Development

21-Jul-2011

ECONOMICS DEPARTMENT

English - Or. English

HOW INSTITUTIONS SHAPE THE DISTRIBUTIVE IMPACT OF MACROECONOMIC SHOCKS:

A DSGE ANALYSIS

ECONOMICS DEPARTMENT WORKING PAPERS No. 884

by Rudiger Ahrend, Charlotte Moeser and Tommaso Monacelli

All Economics Department Working Papers are available through OECD Internet website at http://www.oecd.org/eco/workingpapers

JT03305345

Document complet disponible sur OLIS dans son format d'origine

Complete document available on OLIS in its original format 


\section{ABSTRACT / RÉSUMÉ}

\section{How Institutions Shape the Distributive Impact of Macroeconomic Shocks: A DSGE Analysis}

This paper examines how the the distributive impact of macroeconomic shocks is shaped by selected institutions. It uses a dynamic stochastic general equilibrium (DSGE) framework with heterogeneous agents and an endogenous collateral constraint. The model is based on the "credit view" of business cycles, where shocks affect the real economy also via their impact on the borrowing capacity of economic agents. In this framework a positive shock to credit spreads, as seen in the recent crisis, redistributes from capital to labour as well as from from equity to bond holders. In contrast, both productivity and inflation shocks redistribute towards capital or equity holders. Distributive impacts are shown to be shaped by institutions. More sophisticated financial markets are found to amplify the redistributive impact of shocks, whereas more flexible wages, a more elastic labour supply, and a more reactive central bank are found to dampen it.

JEL Codes: D31; D58; E21; E44

Keywords: DSGE; heterogeneous agents; credit frictions; shocks; income distribution; institutions

***********************************************

\section{Comment les institutions influencent la redistribution liée aux chocs macroéconomiques}

L'article analyse comment les institutions influencent la redistribution qui résulte des chocs macroéconomiques. Premièrement, l'article propose un modèle à agents hétérogènes en équilibre général à dynamique stochastique où les contraintes de crédit sont endogènes. Les chocs macroéconomiques sont transmis à l'activité économique directement et indirectement, via les contraintes de crédit des agents. Dans ce modèle, un choc positif sur les spreads de crédits, comme lors de la dernière crise, affecte moins les agents détenant du travail que ceux qui détiennent du capital, et affecte moins les agents qui détiennent des obligations que des actions. Au contraire, les agents détenant du travail et des obligations sont plus vulnérables aux chocs inflationnistes et aux chocs de productivité. Deuxièmement, l'article évalue comment les institutions influencent la redistribution liée aux chocs macroéconomiques. La sophistication des marchés financiers apparaît amplifier la redistribution liée aux chocs macroéconomiques, tandis que la flexibilité des salaires, l'élasticité de l'offre de travail et la réactivité des banques centrales, apparaissent limiter celle-ci.

Codes JEL: D31 ; D58 ; E21 ; E44

Mots Clés: modèle d'équilibre général à dynamique stochastique; agents hétérogènes; contraintes de crédit ; chocs macroéconomiques ; distribution des revenus ; institutions

\section{Copyright OECD 2011}

Application for permission to reproduce or translate all, or part of, this material should be made to: Head of Publications Service, OECD, 2 rue André-Pascal, 75775 Paris Cedex 16, France. 


\section{TABLE OF CONTENTS}

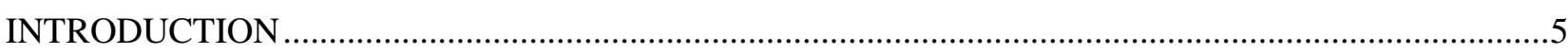

1. Basic Model - Nominal bond holders versus real equity holders.........................................................6

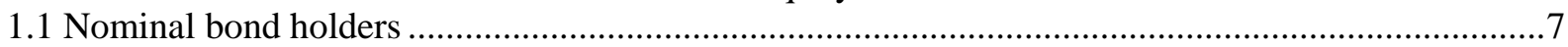

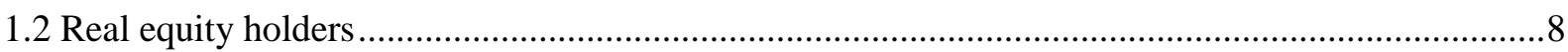

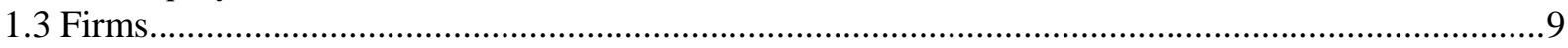

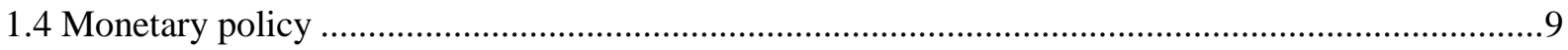

1.5 Credit markets

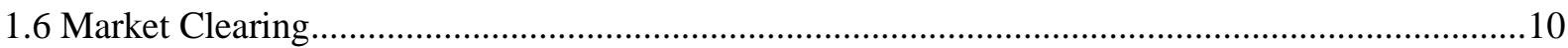

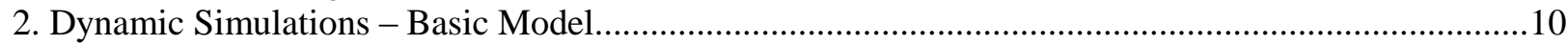

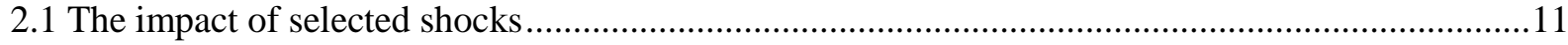

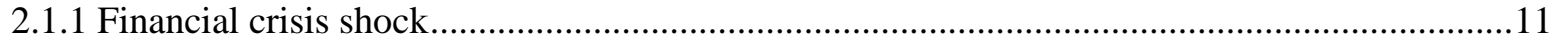

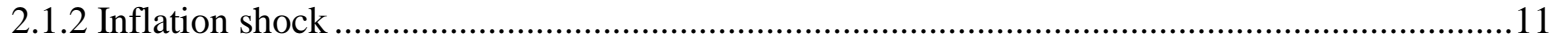

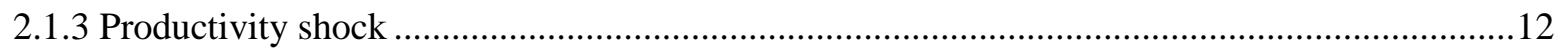



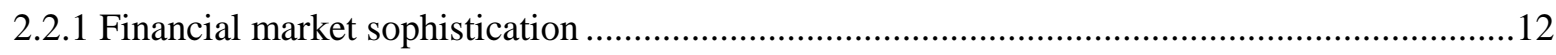

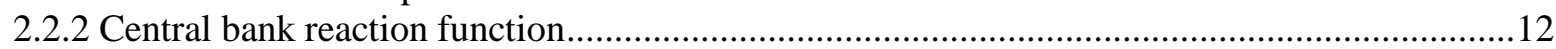

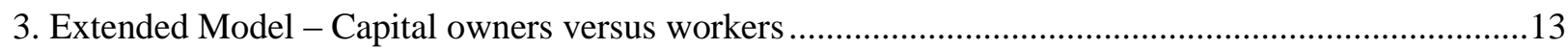

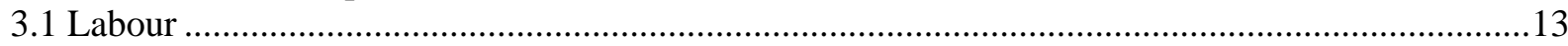

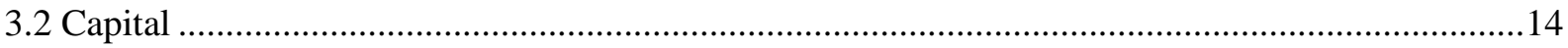

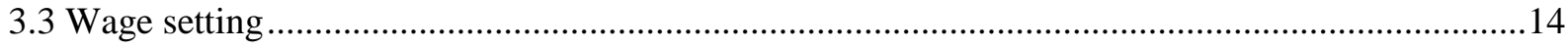

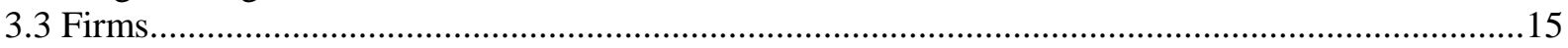

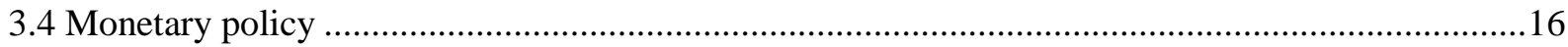

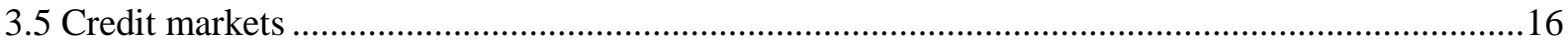

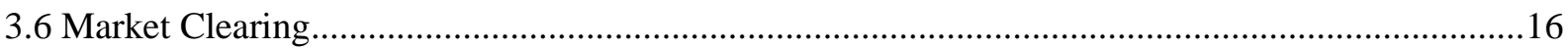



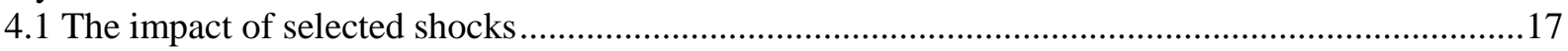

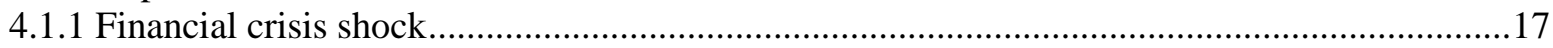

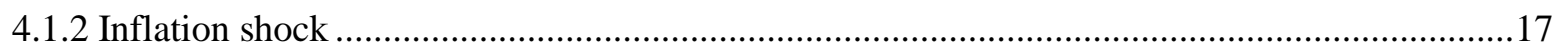

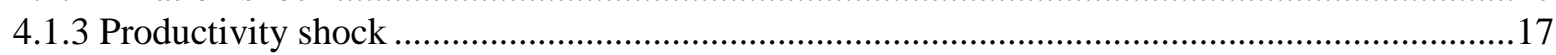

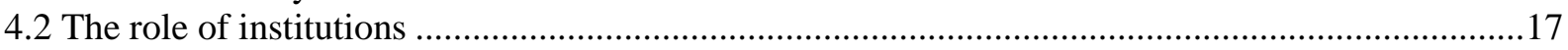

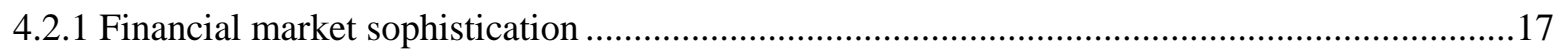

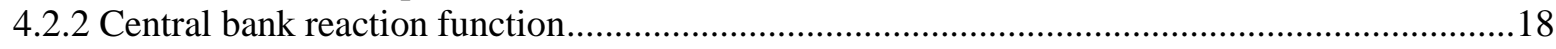

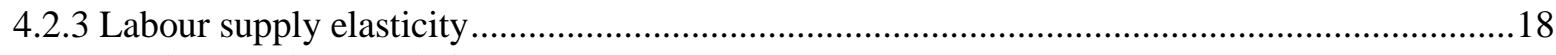

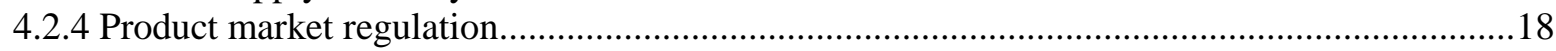

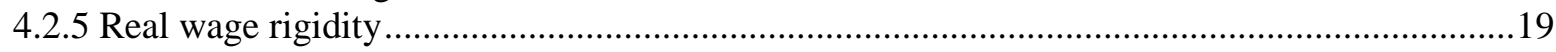

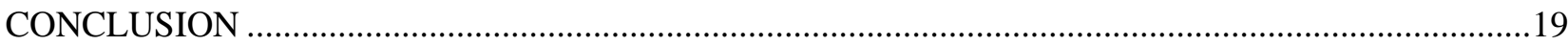

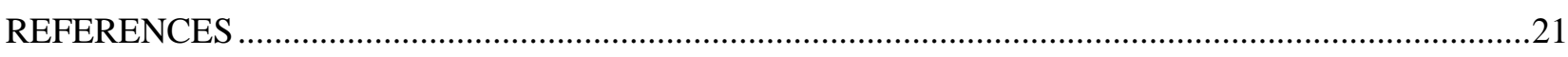

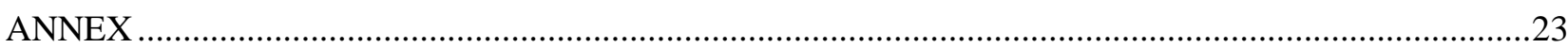




\section{Table}

1. Synthesis of modelling results

\section{Figures}

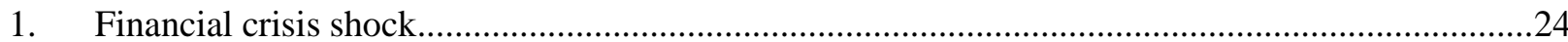

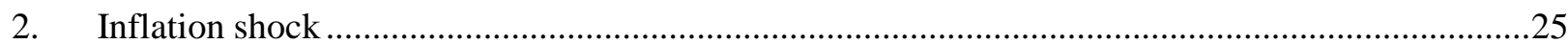

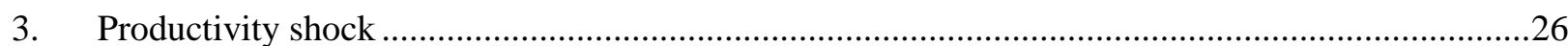

4. Financial crisis shock under different levels of financial market sophistication ............................27

5. Inflation shock under different levels of financial market sophistication........................................28

6. Productivity shock under different levels of financial market sophistication.................................29

7. Financial crisis shock under different central bank reaction functions............................................30

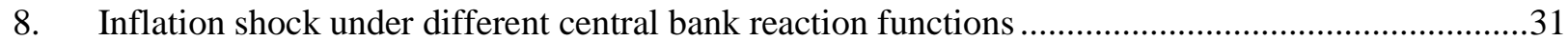

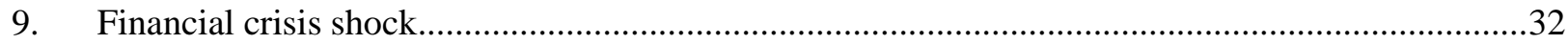

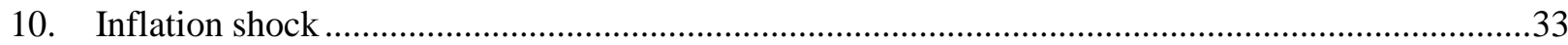

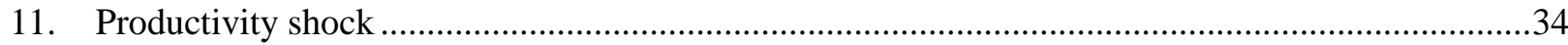

12. Financial crisis shock under different levels of financial market sophistication ............................35

13. Inflation shock under different levels of financial market sophistication......................................36

14. Productivity shock under different levels of financial market sophistication.................................37

15. Financial crisis shock under different central bank reaction functions ............................................38

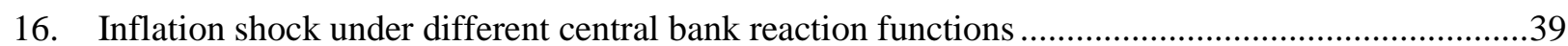

17. Financial crisis shock under different labour supply elasticities ..................................................40

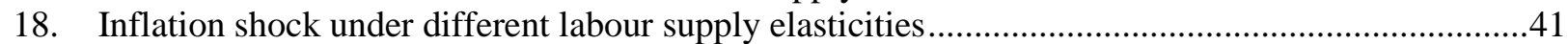

19. Productivity shock under different labour supply elasticities .......................................................42

20. Financial crisis shock under different degrees of PMR ................................................................43

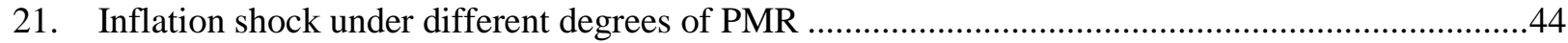

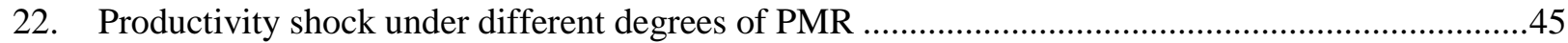

23. Financial crisis shock under different degrees of wage flexibility ................................................46

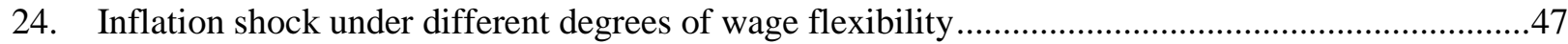

25. Productivity shock under different degrees of wage flexiblity ......................................................48 
ECO/WKP(2011)53

\title{
HOW INSTITUTIONS SHAPE THE DISTRIBUTIVE IMPACT OF MACROECONOMIC SHOCKS: A DSGE ANALYSIS
}

\author{
by \\ Rudiger Ahrend, Charlotte Moeser and Tommaso Monacelli ${ }^{1}$
}

\section{Introduction}

1. Macroeconomic shocks, including financial crises, usually shift income and wealth across different groups (for empirical evidence, see Ahrend et al., 2011). While an extensive literature examines drivers of "steady-state" income inequality, little attention has been devoted to the distributive impact of macroeconomic shocks in the short- and medium term, and almost none to the question of how institutions shape this redistribution. This paper aims to fill the gap by evaluating the distributive impact of economic shocks, and the role of selected institutions in shaping it, in a tractable dynamic stochastic general equilibrium (DSGE) framework with heterogeneous agents. Two models are developed. The baseline model consists of two types of agents that either save via bond holdings, or invest in firms with the proceeds from issuing bonds. The latter, i.e. equity holders face borrowing constraints as they need to collateralise their debt with equity. The second model extends the baseline to a capital versus labour setting. Capital owners resemble the equity holders defined in the first framework. Workers, who also hold nominal bonds, supply labour to firms. In both models, credit markets are subject to frictions.

2. The presented models build on work by Iacoviello (2005) and Calza, Monacelli and Stracca (2010) who develop dynamic general equilibrium frameworks with heterogeneous agents (lenders versus borrowers) and credit constraints. Conceptually, the models are based on the "credit view" of business cycles as formalised by Bernanke and Gertler (1989), incorporating borrowing constraints and collateral requirements as central features. ${ }^{2}$ In such a setting, shocks affect the real economy to a considerable degree via their impact on the borrowing capacity of economic agents. For example, a shock-driven increase in the net worth of borrowers increases the value of their collateral, thereby relaxing their borrowing constraint. The resulting increase in borrowing boosts investment and economic activity. ${ }^{3}$ Correspondingly, drops in asset prices and the implied fall in the value of collateral result in a credit contraction which reduces economic activity. In this set-up, lower credit and falling asset prices not just reflect, but also amplify

1. The authors are indebted to Jens Arnold, Romain Duval, Jørgen Elmeskov, Antoine Goujard, Rossana Merola, Jean-Luc Schneider, delegates to the Working Party No. 1 on Macroeconomic and Structural Policy Analysis, and to colleagues in the OECD Economics Department for useful comments. The authors would also like to thank Celia Rutkoski and Olivier Besson for first rate editorial support. All remaining errors are those of the authors. The views expressed here are those of the authors, and do not necessarily reflect those of the OECD or its member countries.

2. The idea goes back to Fisher's (1933) debt-deflation explanation of the Great Depression. Nolan and Thoenissen (2009) also argue that financial shocks are very tightly linked with the onset of recessions, more so than productivity or monetary shocks.

3. In equilibrium, borrowing constraints are binding. 
recessions. By introducing frictions in credit markets, the presented models also relate to work by Curdia and Woodford (2009). The departure from standard macroeconomic models in which agents directly borrow and invest without financial frictions is in part motivated by the experience of the recent financial crisis where many credit markets ceased to work properly as credit spreads sky-rocketed. ${ }^{4}$

3. Examining questions of redistribution in DSGE models with heterogeneous agents, Doepke and Schneider (2006a; 2006b) argue that inflation shocks can have significant distributive effects and be welfare improving overall even if economic activity declines if one group of agents is financially constrained. Curdia and Woodford (2010) show that by increasing the wedge between the borrowing and lending rates, financial crisis shocks have small effects on aggregate economic activity but important distributive effects. Kiyotaki and Moore (1997), Bacchetta and Caminal (2000), and Monacelli (2009) show that productivity shocks redistribute in relative terms from lenders to borrowers by relaxing the collateral requirements for constrained households.

4. The present paper yields two broad sets of findings:

- Financial crises, defined by increasing credit spreads, redistribute in relative terms from equity to bond holders, as well as from capital to labour. ${ }^{5}$ In contrast, both inflation and productivity shocks redistribute in relative terms from bond to equity holders, as well as from labour to capital.

- As regards institutional settings, more sophisticated financial markets are found to amplify the redistributive impact of shocks, as does a less elastic labour supply and more rigid real wages (reflecting more regulated labour markets). In contrast, a more reactive central bank but also more regulated product markets dampen the redistributive impact of shocks (see Table 1 for a synthesis of modelling results).

5. The paper is structured as follows. Section 1 sets up the baseline model with (nominal) bond holders and (real) equity holders. Section 2 simulates the impact of various shocks with the baseline model and describes their transmission channels. Section 3 extends the baseline framework by introducing capital and labour, and Section 4 reports and discusses simulation results for this extended model.

\section{Basic Model - Nominal bond holders versus real equity holders}

6. The economy is composed of two types of agents with heterogeneous preferences along the lines of Monacelli (2009) and Calza et al. (2010). Each agent, whose time endowment is normalized to one, derives utility from consumption of a final good. One type of agents is assumed to invest in more risky equity, the other to save via bond holdings. ${ }^{6}$ Agents differ also in their degree of patience regarding consumption. The less patient agents borrow money by issuing bonds. These bonds are bought by the more patient agents, which therewith become holders of nominal assets. ${ }^{7}$ The bond issuers use levied funds to

4. For related contributions see also Goodfriend and McCallum (2007) and De Fiore and Tristani (2007).

5. Redistribution as measured by current consumption units in the wake of macroeconomic shocks (not in net present value terms).

6. Agents investing in equity are subject to borrowing constraints. From a technical point of view, this modelling friction implies that equity holdings are more risky since their price is more strongly affected by shocks.

7. Debt accumulation reflects inter-temporal trading between the bond holder (saver) and the equity holder (borrower). In equilibrium, the patient agent (bond holder) will end up being the net lender, while the impatient agent (equity holder) will be the net borrower. 
invest in firms, and consequently hold real assets, i.e. shares of the capital stock of firms. Bond holders and equity holders obtain income from, respectively, interest payments and dividends. Equity holders are credit-constrained with their borrowing capacity being limited by the value of their collateral (i.e. their equity). Financing frictions resulting from the collateral requirement act like an accelerator amplifying the impact of shocks. For example, a rise in asset prices in the aftermath of a productivity shock increases the value of collateral and consequently the borrowing capacity. This, in turn, further boosts investment and economic activity. Assuming that real asset holders borrow to finance part of their equity is a simple stylised way to capture the fact that equity holders are generally either directly or indirectly leveraged. More precisely, equity holders may either be thought of as entrepreneurs who borrow to create their enterprise, or as shareholders in large enterprises who are indirectly leveraged as a large part of the enterprises' capital stock is financed by borrowing.

7. The production structure is relatively standard, with a competitive firm producing a final good. In the extended version of the model presented later in this paper the competitive final good producer purchases differentiated intermediate goods produced by monopolistic competitive firms.

\subsection{Nominal bond holders}

8. Bond holders maximise their utility by choosing optimal sequences for $C_{b, t}, B_{b, t}$ and $K_{b, t}$ :

$$
\max E_{0}\left\{\sum_{t=0}^{\infty} \gamma^{t} \log C_{b, t}\right\},
$$

subject to the budget constraint:

$$
P_{c, t} C_{b, t}+P_{k, t}\left(K_{b, t}-K_{b, t-1}\right)-B_{b, t} \leq-R_{t-1} B_{b, t-1}+P_{c, t} Y_{b, t}
$$

$\gamma$ is the discount factor of the bond holders. Households save by acquiring nominal bonds $B_{b, t}$ issued by equity holders (note that as $B_{b, t}$ describes the amount of bonds issued by an agent, it is negative for holders of bonds). For simplicity, bonds are modelled to mature every period, with $R_{t}$ being the short-term nominal interest rate on nominal loan contracts stipulated at time $t-1$, implying that debt contracts between bond and equity holders are predetermined in nominal terms. $C_{b, t}$ is bond holders' real consumption, $K_{b, t}$ capital held by bond holders and used in relatively inefficient home production, and $P_{k, t}$ the price of capital goods. For a given level of debt, a rise in inflation lowers the current real burden of debt repayments. Thus, inflationary shocks can affect the borrowers' net worth and may have redistributive effects (from bond holders to equity holders). $P_{c, t}$ is the consumer price index, and $P_{c, t} Y_{b, t}$ is the income bond holders obtain from productive capital they use for some kind of relatively inefficient home production (e.g. gardening or house maintenance):

$$
Y_{b, t}=K_{b, t}^{\omega} .
$$

9. The efficiency conditions for the bond holders' optimal program are the standard Euler equation:

$$
\frac{1}{C_{b, t}}=\gamma R_{t} E_{t}\left\{\frac{P_{c, t}}{C_{b, t+1} P_{c, t+1}}\right\}
$$


and the capital demand condition:

$$
\frac{q_{t}}{C_{b, t}}=\gamma E_{t}\left\{\frac{1}{C_{b, t+1}}\left[q_{t+1}+Y_{b, t}^{\prime}\left(K_{b, t}\right)\right]\right\},
$$

with $q_{t}=\frac{P_{k, t}}{P_{c, t}}$ being the price of capital in real terms and $\left[q_{t+1}+Y_{b, t}^{\prime}\right]$ the real rate of return on capital owned by bond holders.

\subsection{Real equity holders}

10. Equity holders maximise their utility by choosing optimal sequences for $C_{e, t}, B_{e, t}$ and $K_{e, t}$ :

$$
\max E_{0}\left\{\sum_{t=0}^{\infty} \beta^{t} \log C_{e, t}\right\}
$$

where $\beta<\gamma$ as equity holders are by assumption less patient than bond holders. Maximisation is done subject to the budget constraint:

$$
P_{c, t} C_{e, t}+P_{k, t}\left(K_{e, t}-K_{e, t-1}\right)-B_{e, t} \leq R_{t}^{k} K_{e, t-1}-R_{t-1} B_{e, t-1}
$$

$C_{e, t}$ is equity holders' consumption, $K_{e, t}$ is equity in form of invested capital, $P_{k, t}$ is the price of capital, $R_{t}$ the bond yield, and $R_{t}^{k}$ the dividend yield on capital invested in firms.

Equity holders are credit-constrained in the sense that they have to provide collateral to borrow:

$$
R_{t} B_{e, t} \leq(1-\chi) E_{t}\left\{P_{k, t+1} K_{e, t}\right\}
$$

At any time $t$, the amount that the equity holder agrees to repay in the following period $R_{t} B_{t}$ is tied to the expected value of the collateral $E_{t}\left\{P_{k, t+1} K_{e, t}\right\} \cdot \chi$ is the fraction of the capital value that cannot be used as collateral. Note that expected movements in asset prices directly affect the capacity to borrow. Financing frictions as in the preceding equation act like an accelerator in case of a shock. For example, a rise in asset prices $E_{t}\left\{P_{k, t+1}\right\}$ in the aftermath of a shock increases the value of collateral. The ensuing rise in the borrowing capacity pushes up borrowing, investment, and economic activity.

11. First-order conditions yield the Euler condition:

$$
\frac{1}{C_{e, t}}=\beta R_{t} E_{t}\left\{\frac{P_{c, t}}{C_{e, t+1} P_{c, t+1}}\right\}+\psi_{t} R_{t} \frac{1}{C_{e, t}}
$$

and the capital demand condition: 


$$
\frac{q_{t}}{C_{e, t}}=\beta E_{t}\left\{\frac{q_{t+1}+r_{k, t+1}}{C_{e, t+1}}\right\}+(1-\chi) \psi_{t} \frac{E_{t}\left\{q_{t+1} \pi_{t+1}\right\}}{C_{e, t}}
$$

where $q_{t}=\frac{P_{k, t}}{P_{c, t}}$ and $r_{k, t}=R_{k, t} / P_{c, t}$ are asset prices and dividend yields, respectively, in real terms. $\pi_{t}$ is the change in the consumer price index. $\psi_{t}$ is the marginal value of borrowing; a rise in $\psi_{t}$ implies a tightening of the collateral constraint. ${ }^{8}$

\subsection{Firms}

12. Firms use the capital invested by equity holders to produce output:

$$
Y_{t}=A_{t} K_{e, t-1}^{\alpha}
$$

where $A_{t}$ is a technology subject to a shock assumed to evolve according to:

$$
\exp \left(a_{t}\right)=\exp \left(a_{t-1}\right)^{\rho_{a}} u_{a, t}
$$

with $u_{a, t} \sim$ iid and $0<\rho_{a}<1$. In competitive equilibrium it must hold that:

$$
r_{t}^{k}=A_{t} \alpha K_{e, t-1}^{\alpha-1}
$$

\subsection{Monetary policy}

13. Monetary policy is conducted following a simplified Taylor rule:

$$
\frac{R_{P R, t}}{R^{*}}=\left(\frac{\pi_{t}}{\pi_{t}^{*}}\right)^{\varphi_{\pi}} \varepsilon_{t}
$$

where $R_{R P, t}$ is the nominal (policy) interest rate, $R^{*}$ is the steady-state nominal interest rate (the "neutral" rate), and $\varphi_{\pi}$ is the Taylor coefficient on inflation signalling the stance of monetary policy. ${ }^{9} \pi_{t}$ is the change in consumer prices (more precisely the ratio of the price level in t and $\mathrm{t}-1$, implying that with an inflation rate of zero, $\pi_{t}$ is equal to 1$) . \pi^{*}$ is the central bank target for the change in consumer prices, and $\varepsilon_{t}$ is a policy shock which is assumed to evolve according to:

$$
\exp \left(\varepsilon_{t}\right)=\exp \left(\varepsilon_{t-1}\right)^{\rho_{\varepsilon}} u_{\varepsilon, t}
$$

with $u_{\varepsilon, t} \sim$ iid and $0<\rho_{\varepsilon}<1$.

8. The marginal value on borrowing ${ }^{t}$ is also the Lagrange multiplier of the borrowing constraint.

9. A larger coefficient $\varphi_{\pi}$ reflects a more reactive policy to deviations of inflation from target. 


\subsection{Credit markets}

14. The recent crisis has underscored the importance of imperfections in financial intermediation. Therefore the model features frictions in credit markets. More precisely, borrowing and lending is assumed to be subject to real resource costs $\Phi$ that drive a wedge between the policy rate and the bond rate, thus giving rise to credit spreads: ${ }^{10}$

$$
R_{t}=R_{P R, t}(1+\Phi) \zeta_{t}
$$

where $\zeta_{t}$ is an exogenous shock to the credit spread, which is assumed to evolve according to:

$$
\exp \left(\zeta_{t}\right)=\exp \left(\zeta_{t-1}\right)^{\rho_{\zeta}} u_{\zeta, t}
$$

with $u_{\zeta, t} \sim$ iid and $0<\rho_{\zeta}<1$.

\subsection{Market Clearing}

15. Equilibrium in the debt, consumption and capital markets requires, respectively:

$$
\begin{gathered}
B_{b, t}+B_{e, t}=0 \\
C_{b, t}+C_{e, t}=Y_{t} \\
K_{b, t}+K_{e, t}=\bar{K}
\end{gathered}
$$

Finally, there is no redistribution via fiscal policy, which is ignored in this model.

\section{Dynamic Simulations - Basic Model}

16. This section uses the previous model to assess the dynamic adjustment of variables in response to financial crisis, inflation and technology shocks. It first illustrates the transmission mechanisms of shocks with a particular focus on distributive consequences for bond and equity holders, before analysing the role of institutions in shaping the transmission of these shocks. The institutional features considered are financial market sophistication as reflected by the parameter $\chi$, and the strength of the reaction of the central bank to deviations of inflation from target as reflected in the Taylor-rule coefficient $\varphi^{\pi}$. Parameters of the model are calibrated to commonly used values, ${ }^{11}$ with time being in quarters. Equity and bondholders' discount factors are set to $\beta=0.98$ and $\gamma=0.99$, respectively. The interest rate is directly related to the bond holders' discount factor through $R^{*}=(1 / \gamma)^{4}$ implying that. $R^{*}=1.04$, i.e. an annual interest rate of $4 \%$. The parameter $\chi$ which characterises the borrowing constraint is fixed at 0.25 , implying that shareholders can borrow up to $75 \%$ of the value of their equity. For simplicity $\pi^{*}$ is assumed to be equal to 1, implying that the central bank targets an inflation rate of zero. Finally, the Taylor rule

10. In more detailed descriptions of credit market frictions, the size of credit spreads also depends on the amount of credit supplied (see Curdia and Woodford, 2010).

11. Parameters are calibrated to commonly used values that mirror characteristics from different economies. Parameter values are hence not tailored to a specific country. 
parameter $\varphi^{\pi}$ is set to equal 1.5 and the persistence of the monetary policy innovation $\rho_{\varepsilon}$ to 0.7 . The persistence of the productivity shock is $\rho_{a}=0.95$ and that of the financial crisis shock is $\rho_{\zeta}=0.7$. All variables are expressed in percentage deviations from steady state.

\subsection{The impact of selected shocks}

\subsubsection{Financial crisis shock}

17. A financial crisis shock, defined as an unanticipated increase in credit spreads, leads to redistribution (in relative terms) from equity to bond holders, though bond holders' consumption increases by far less than equity holders' consumption decreases (Figure 1). Redistribution works through two channels: ${ }^{12}$

- Bondholders, whose income is derived primarily from interest payments, benefit from higher bond yields and a positive wealth effect from the disinflation brought about by the crisis. ${ }^{13}$ By contrast, higher borrowing costs affect equity holders negatively. The implied reduction in overall borrowing and investment reduces economic activity. Lower activity and higher bond yields, in turn, reduce asset prices and dividends, further hitting equity holders who moreover suffer a negative wealth effect from disinflation.

- Lower asset prices reduce the value of collateral, and the associated tightening of borrowing constraints reinforces the fall in investment and economic activity. Hence, the borrowing constraint acts like an accelerator that amplifies redistribution from equity to bond holders in the event of financial crises.

\subsubsection{Inflation shock}

18. An upward inflation shock, defined as an unexpected increase in inflation, redistributes wealth from bond holders to equity holders via the following two channels:

- As debt contracts are predetermined in nominal terms, inflation directly reduces the real value of debt, thereby lowering the burden of debt payments and shifting wealth from the bond holder to the equity holder. ${ }^{14}$

- The increase in inflation triggers a boom in economic activity and asset prices as the borrowing constraint functions like an accelerator: increases in the nominal value of collateral together with unchanged nominal debt relax the credit constraint and - by boosting borrowing and investment amplify the economic boom. Overall, consumption of equity holders increases strongly (Figure 2) due to higher dividend income and the aforementioned positive wealth effect. Consumption of bond holders decreases, as the negative real wealth effect of the inflation shock outweighs increases in income from both expanded lending and the rising real interest rate required to bring inflation back to target. Correspondingly, disinflation or deflation shocks lead to a decrease in

12. All figures display the dynamic response to a unit shock.

13. The positive wealth shock from unexpected disinflation occurs in one period only, but is then carried forward dynamically.

14. The wealth effect from unexpected inflation occurs in one period only, but has lasting effects driven e.g. by higher levels of investment under a loosened collateral constraint. 
borrowing, investment and economic activity, and together with a negative wealth effect from rising real debt, redistribute away from equity holders.

\subsubsection{Productivity shock}

19. A rise in productivity strongly boosts consumption possibilities of equity holders, while those of bond holders remain largely unaffected (Figure 3 ). ${ }^{15}$ Technological innovation makes production more efficient and hence increases dividends and asset prices (the latter reflecting the discounted value of future profits). The increase in asset prices raises the value of collateral, relaxing the credit constraint of equity holders and expanding their capacity to borrow and invest. This further accelerates the initial increase in economic activity.

\subsection{The role of institutions}

20. Simulations show that more sophisticated financial markets amplify the redistributive impact of the shocks under consideration, whereas a stronger central bank reaction function dampens it. These interactions with institutions are examined in turn below.

\subsubsection{Financial market sophistication}

21. More developed and sophisticated financial markets should relax borrowing constraints, for example through better possibilities for lenders to assess or share risk or through improved legal security of their claims. ${ }^{16}$ A relaxation of borrowing constraints could also result from increased competition, or less stringent financial market regulation. More sophisticated or more competitive financial markets as reflected in lower borrowing constraints (i.e. a lower $\chi$ ) intensify the financial accelerator effect as the fall in the price of collateral restricts borrowing possibilities more when agents are initially more leveraged. Consequently, more sophisticated financial markets amplify the redistribution from equity to bondholders that results from financial crises (Figure 4), as well as the redistribution from bond to equity holders resulting from positive inflation and productivity shocks (see Figures 5 and 6).

\subsubsection{Central bank reaction function}

22. Two scenarios are considered which differ in the strength of the central bank reaction as reflected in the Taylor coefficient. ${ }^{17}$ In the framework of the model, a more responsive central bank dampens the redistributive impact of the shocks considered. For example, financial crisis shocks redistribute less towards bond holders, essentially because larger policy rate cuts reduce the negative impact of financial crises on investment and growth (Figure 7). Similarly, upward inflation shocks redistribute less towards equity holders, as larger increases in the policy rate dampen the negative wealth effects on bond holders, and mitigate the boom in activity and asset prices from which equity holders benefit (Figure 8).

15. Note that bond holders are standard permanent-income agents. When hit by a positive income shock, bond holders substitute consumption inter-temporally, i.e. saving and consumption levels increase while the saving rate declines. Equity holders are more impatient, thus saving a smaller and consuming a larger portion than more patient bond holders when hit by a positive income shock. Bond holders' consumption is therefore less responsive to income shocks than equity holders'.

16. $\chi$ is set to 0.25 to proxy for a lower, and to 0.20 to proxy for a higher degree of financial market sophistication.

17. $\varphi$ is set to 1.5 as a baseline, and to 2 to proxy for a stronger central bank reaction. 


\section{Extended Model - Capital owners versus workers}

23. The extended model considers capital owners and workers. Most features are the same as in the basic model: one group of agents holds shares of the capital stock of firms, receiving dividends as the main source of income. These agents are credit-constrained and have to provide collateral (capital) to borrow. The other group of agents (workers) holds nominal assets and - this being the main difference from Model 1 - also supply labour to firms. Consequently, workers obtain labour income and interest payments. Both types of agents consume output produced by firms that use capital and labour as inputs into production. The final-good producer purchases differentiated intermediate goods produced by monopolistic competitive firms that exert market power to obtain mark-ups over the competitive price level. Price setting is subject to adjustment costs as in Rotemberg (1982). Also, real wages are assumed to respond sluggishly to labour market conditions as a result of frictions in labour markets (Blanchard and Gali, 2007).

\subsection{Labour}

24. Workers maximise the utility function by choosing optimal sequences for $C_{l, t}, L_{t}, B_{l, t}$ and $K_{l, t}$ :

$$
\max E_{0}\left\{\sum_{t=0}^{\infty} \gamma^{t} \log C_{l, t}-\phi \frac{L_{t}^{1+v}}{1+v}\right\}
$$

subject to the budget constraint:

$$
P_{c, t} C_{l, t}+P_{k, t}\left(K_{l, t}-K_{l, t-1}\right)-B_{l, t} \leq-R_{t-1} B_{l, t-1}+P_{c, t} Y_{l, t}+W_{t} L_{t}
$$

where $\gamma$ is the discount rate of the worker, $L_{t}$ is labour supply, $v$ is the inverse of the (Frisch) labour supply elasticity, $\phi$ is the preference for leisure, $R_{t}$ is the short-term nominal interest rate of the bond $B_{l, t}$, $K_{l, t}$ is capital held by workers (for relatively inefficient home production), and $P_{k, t}$ is the price of capital goods. $W_{t} L_{t}$ is (nominal) wage income and $P_{c, t} Y_{l, t}$ is the income workers obtain from home production:

$$
Y_{l, t}=K_{l, t}^{\omega} .
$$

25. First order conditions imply the Euler equation:

$$
\frac{1}{C_{l, t}}=\gamma R_{t} E_{t}\left\{\frac{P_{c, t}}{C_{l, t+1} P_{c, t+1}}\right\}
$$

and the capital demand:

$$
\frac{q_{t}}{C_{l, t}}=\gamma E_{t}\left\{\frac{1}{C_{l, t+1}}\left[q_{t+1}+Y_{l, t}^{\prime}\left(K_{l, t}\right)\right]\right\}
$$

with $q_{t}=\frac{P_{k, t}}{P_{c, t}}$ and $\left[q_{t+1}+Y_{l, t}^{\prime}\right]$ being the real price of capital and the real rate of return on capital owned by the worker. The condition for labour supply is:

$$
\phi L_{t}^{v}=\frac{W_{t}^{*}}{P_{c, t} C_{l, t}} .
$$




\subsection{Capital}

26. Capital owners resemble the equity holders described in Model 1. Capital owners are more impatient than workers, implying $\gamma>\beta$. Utility is maximised:

$$
\max E_{0}\left\{\sum_{t=0}^{\infty} \beta^{t} \log C_{c, t}\right\} \gamma>\beta
$$

subject to the budget constraint:

$$
P_{c, t} C_{c, t}+P_{k, t}\left(K_{c, t}-K_{c, t-1}\right)-B_{c, t} \leq R_{t}^{k} K_{c, t-1}-R_{t-1} B_{c, t-1}
$$

where $\beta$ is the discount rate of the capital holder, $C_{c, t}$ their consumption and $K_{c, t}$ their capital holdings (shares). $P_{k, t}$ is the price of capital goods, $R_{t}$ is the (short-term) nominal interest rate of the bond $B_{c, t}$, and $R_{t}^{k}$ the dividend yield. Capital owners face a borrowing constraint and need to provide collateral to borrow:

$$
R_{t} B_{c, t} \leq(1-\chi) E_{t}\left\{P_{k, t+1} K_{c, t}\right\}
$$

where $E_{t}\left\{P_{k, t+1} K_{c, t}\right\}$ is the expected value of collateral owned by the capital holder and $\chi$ the fraction of capital that cannot be used as collateral. First order conditions imply the Euler condition:

$$
\frac{1}{C_{c, t}}=\beta R_{t} E_{t}\left\{\frac{P_{c, t}}{C_{c, t+1} P_{c, t+1}}\right\}+\psi_{t} R_{t} \frac{1}{C_{c, t}}
$$

and the capital demand condition:

$$
\frac{q_{t}}{C_{c, t}}=\beta E_{t}\left\{\frac{1}{C_{c, t+1}}\left[q_{t+1}+\alpha A_{t+1} K_{c, t}^{\alpha-1}\right]\right\}+(1-\chi) \psi_{t} \frac{E_{t}\left\{q_{t+1}\right\}}{C_{c, t}} \frac{P_{c, t+1}}{P_{c, t}}
$$

\subsection{Wage setting}

27. Following Blanchard and Gali (2007), real wages are assumed to respond sluggishly to labour market conditions as a result of frictions in labour markets. More precisely, real wages adjust slowly to their equilibrium level in the aftermath of a shock, i.e. they are modelled as the weighted average of the past wage level and the equilibrium wage level:

$$
W_{t}=\rho_{w} W_{t-1}+\left(1-\rho_{w}\right) W_{t}^{*},
$$

where $\rho_{w}$ can be interpreted as an index of real wage rigidity. ${ }^{18}$

18. An important underlying assumption is that the slow adjustment results from distortions rather than preferences. 


\subsection{Firms}

28. The production sector is comprised of a representative final-goods-producing firm, and a continuum of intermediate-goods-producing firms indexed by $i \in[0,1]$ characterised by staggered pricesetting as in Rotemberg (1982). Intermediate-goods-producing firms are assumed to be monopolistically competitive, i.e. they exert market power to obtain mark-ups over the competitive price level.

29. The final-goods firm uses $Y_{t}(i)$ units of each intermediate good $i \in[0,1]$, purchased at nominal price $P_{t}(i)$, to produce $Y_{t}$ units of the finished product using a constant returns-to-scale technology:

$$
\left[\int_{0}^{1} Y_{t}(i)^{\frac{\theta-1}{\theta}} d i\right]^{\frac{\theta}{\theta-1}} \geq Y_{t}
$$

where $\theta>1$. A higher $\theta$ implies a lower degree of monopolistic competition, and hence less power of intermediate-goods firms to set prices. The final-goods-producing firm chooses $Y_{t}(i)$ for all $i \in[0,1]$ to maximise its profits:

$$
P_{t}\left[\int_{0}^{1} Y_{t}(i)^{\frac{\theta-1}{\theta}} d i\right]^{\frac{\theta}{\theta-1}}-\int_{0}^{1} P_{t}(i) Y_{t}(i) d i
$$

Competition drives the final-goods-producing firm's profit to zero at the equilibrium. It can be shown (see e.g. Faia and Monacelli, 2008) that the zero profit condition for the final-goods-producing firm implies that

$$
P_{t}=\left[\int_{0}^{1} P(i)^{1-\theta} d i\right]^{\frac{1}{1-\theta}} .
$$

30. Intermediate-good firms produce according to a standard production function using as inputs capital provided by capital owners and labour provided by workers:

$$
Y_{t}(i)=A_{t} K_{c, t-1}^{\alpha}(i) L_{t}^{\alpha}(i)
$$

Since the intermediate goods are not perfect substitutes in the production of final goods, the intermediategoods firms face an imperfectly competitive market. During each period $t$ each firm sets the nominal price of its output. The firm faces a quadratic adjustment cost for nominal price changes given by:

$$
\frac{\phi_{p}}{2}\left[\frac{P_{t}(i)}{P_{t-1}(i)}-1\right]^{2} Y_{t},
$$

where $\phi_{p}>0$ reflects the importance of adjustment costs. This relationship, as stressed in Rotemberg (1982), could be interpreted as accounting for the negative effects of price changes on customer-firm relationships. Such negative effects are modelled to increase in magnitude with the size of the price change and with the overall scale of economic activity. The firm chooses $\left\{P_{t}(i), L(i)\right\}$ to maximize future expected profits:

$$
E_{0} \sum_{t=0}^{\infty} \gamma^{t}\left(P_{t}(i) Y_{t}(i)-L_{t}(i) W_{t}-R_{t}^{k} K_{c, t-1}-\frac{\phi_{p}}{2}\left[\frac{P_{t}(i)}{P_{t-1}(i)}-1\right]^{2} Y_{t}\right.
$$


First order conditions yield:

$$
\begin{gathered}
r_{t}^{k}=A_{t} \alpha K_{e, t-1}^{\alpha-1}, \\
w_{t}=(1-\alpha) Y_{t} / L_{t} m c_{t}, \\
\phi_{p}\left(\pi_{t}-1\right) \pi_{t}=\theta\left(m c_{t}-((\theta-1) / \theta)\right)+\gamma \phi_{p}\left(C_{l, t} / C_{l, t+1}\right)_{t}\left(\pi_{t+1}-1\right) \pi_{t+1}\left(Y_{t+1} / Y_{t}\right),
\end{gathered}
$$

with $m c_{t}$ being the marginal cost of firms. The last equation is the New Keynesian Phillips curve in its non-linearised form, where firms set prices as a mark-up over marginal costs, accounting for costly expected future price adjustments.

\subsection{Monetary policy}

31. As in the basic model above, monetary policy follows a simplified Taylor rule:

$$
\frac{R_{P R, t}}{R^{*}}=\left(\frac{\pi_{t}}{\pi_{t}^{*}}\right)^{\varphi_{\pi}} \varepsilon_{t}
$$

with $\varepsilon_{t}$ being a policy shock assumed to evolve according to $\exp \left(\varepsilon_{t}\right)=\exp \left(\varepsilon_{t-1}\right)^{\rho_{\varepsilon}} u_{\varepsilon, t}$.

\subsection{Credit markets}

32. Credit market frictions give rise to credit spreads as in the previous model. The bond rate is hence

$$
R_{t}=R_{P R, t}(1+\Phi) \zeta_{t}
$$

where $\zeta_{t}$ is an exogenous shock to the credit spread, which is assumed to evolve according to $\exp \left(\zeta_{t}\right)=\exp \left(\zeta_{t-1}\right)^{\rho_{\zeta}} u_{\zeta, t}$ with $u_{\zeta, t} \sim$ iid and $0<\rho_{\zeta}<1$.

\subsection{Market Clearing}

33. Given that the model contains no redistribution via fiscal policy, equilibrium in the debt, consumption and capital markets requires, respectively:

$$
\begin{gathered}
B_{c, t}+B_{l, t}=0, \\
C_{c, t}+C_{l, t}=Y_{t}, \\
K_{c, t}+K_{l, t}=\bar{K} .
\end{gathered}
$$

\section{Dynamic simulations - Extended Model}

34. This section first presents impulse-response functions to illustrate the transmission channels of productivity, inflation and financial crisis shocks. It then looks at the role of different institutional features in shaping the transmission of shocks. In addition to financial market sophistication and the reaction 
function of the central bank, the impact of the elasticity of labour supply, product market regulation (PMR) and wage flexibility are evaluated:

- Differences in the labour supply elasticity may partly reflect underlying institutions. For example, means-tested benefits may lower labour-supply elasticities.

- Stricter product market regulation $(P M R)$ increases the monopolistic power of firms, which in turn allows them to charge higher mark-ups on prices.

- Low wage flexibility may reflect frictions arising through preferences, labour market institutions, or the tax and benefit system. Possible examples are wage loss aversion, fairness considerations, union power, collective wage bargaining, minimum wages, unemployment benefits, or tax wedges.

35. The parameters are calibrated to the same commonly used values as in Model 1 . The steady-state real rate of interest ("neutral" rate) $R^{*}$ is fixed at 4\%, the workers' discount rate $\gamma$ at 0.99 and the capital owners' discount rate $\beta$ at 0.98 . The parameter $\chi$, which reflects the borrowing constraint, is set to 0.25 , the Taylor rule parameter $\varphi_{\pi}$ to 1.5 and the persistence of the monetary policy innovation $\rho_{\varepsilon}$ to 0.7 . The persistence of the productivity shock is $\rho_{a}=0.95$ and of the financial crisis shock $\rho_{\zeta}=0.7$. Finally, the inverse of the Frisch elasticity of labour supply $v$ is assumed to be 1.5 .

\subsection{The impact of selected shocks}

\subsubsection{Financial crisis shock}

36. Both labour and capital income decrease in the wake of a financial crisis shock due to the decline in economic activity. However, capital owners are also hit by a negative wealth effect from declining asset prices, resulting in a comparatively larger fall in their consumption (Figure 9).

\subsubsection{Inflation shock}

37. An upward inflation shock redistributes from workers to capital owners. Capital owners benefit as they experience a positive wealth effect from the decrease in the real value of their borrowing while the real value of their assets does not suffer. Augmented borrowing capacities and the resulting strengthening in economic activity raise asset prices further, and thereby reinforce redistribution towards capital owners (Figure 10).

\subsubsection{Productivity shock}

38. Workers' and capital owners' incomes increase with stronger economic activity, but the relative position of workers deteriorates due to the positive wealth effect on capital owners from increasing asset prices (Figure 11).

\subsection{The role of institutions}

\subsubsection{Financial market sophistication}

39. As in Model 1, more sophisticated financial markets increase the redistributive impact of the shocks under consideration (Figures 12-14). A higher degree of financial market sophistication increases the sensitivity of borrowing to changes in the value of collateral. Financial crises, which end up having 
stronger negative effects on asset prices when financial markets are more sophisticated, result therefore in added redistribution from capital owners to workers. Both inflation and productivity shocks lead to increases in the value of collateral that have larger positive effects on borrowing, investment and economic activity when financial markets are more sophisticated. Stronger asset price increases in an economy with more sophisticated financial markets also imply a larger relative redistribution from workers to capital owners.

\subsubsection{Central bank reaction function}

40. In concordance with the findings of the basic model, a more reactive central bank dampens the redistributive impact of all shocks (Figures 15-16). For example, financial crisis shocks redistribute less towards workers, essentially because larger policy rate cuts reduce the negative impact on economic activity, and hence on asset prices, implying smaller negative wealth effects for capital owners. Similarly, upward inflation shocks redistribute less towards capital owners, as larger policy rate increases dampen the positive wealth effects from rising inflation for capital owners.

\subsubsection{Labour supply elasticity}

41. The impact of changes in the labour supply elasticity is examined by simulating the different shocks with both $v=1.5$ (high labour supply elasticity) and $v=3$ (low labour supply elasticity). ${ }^{19}$ Figures 17-19 display the impulse response functions. The simulations show that a less elastic labour supply tends to reinforce the redistributive impact of shocks. A positive productivity shock induces firms to raise production, leading to increased demand for capital and labour. If labour supply is less elastic, firms effectively substitute capital for labour by opting for larger increases in investment, and the resulting increase in asset prices reinforces the redistribution of productivity shocks from labour to capital. Similarly, a less elastic labour supply reinforces the redistributive impact of positive inflation shocks towards capital as the substitution of capital for labour increases asset prices, although only in the short term. Finally, a less elastic labour supply amplifies the relative redistribution from capital owners to workers caused by financial crises. This effect, which again holds only in the short term, arises because slower adjustment in the labour market results in lower investment and asset prices.

\subsubsection{Product market regulation}

42. Stricter product market regulation increases the monopolistic power of firms, which in turn allows them to charge higher mark-ups on prices. Two scenarios are considered, one corresponding to a high mark-up reflecting relatively strict product market regulation $(\theta=4)$, and another corresponding to relatively low levels of product market regulation $(\theta=12)$. Figures 20-22 display the impulse response functions. More regulated product markets dampen the redistributive impact of the considered shocks. In more strictly regulated product markets, firms increase production significantly less following a positive productivity shock. This results in lower asset price increases, lowers borrowing and investment by firms, and consequently dampened the redistribution towards capital holders. Similarly, in the wake of positive inflation shocks stricter product market regulation dampens redistribution towards capital holders, again reflecting smaller increases in output, asset prices, borrowing and investment. More regulated product markets also reduce the redistributive effect from financial crises towards workers by mitigating the fall in output and asset prices.

43. However, the DSGE model only allows for a static effect from PMR: simply equating stricter PMR with a higher mark-up mechanically leads to a lower elasticity of investment and hence of output to

19. The parameter $v$ corresponds to the inverse Frisch elasticity of labour supply, i.e. a rise in $v$ implies a reduction in labour supply elasticity. 
the shocks considered. In reality, stricter PMR can also prevent or slow down necessary reallocation in the aftermath of shocks (Arnold et al., 2008), thereby potentially increasing their adverse output effects. This effect is not captured by the model, but may outweigh the included static effect. For example, the econometric analysis in Ahrend et al. (2011) points to stricter PMR increasing the redistributive effects of adverse macroeconomic shocks.

\subsubsection{Real wage rigidity}

44. In the model, two scenarios are considered, reflecting low $\left(\rho_{w}=0\right)$ and high $\left(\rho_{w}=0.6\right)$ degrees of real wage rigidity. Figures 23-25 display the impulse-response functions. Low wage flexibility amplifies the redistributive impact of all shocks. Under a financial crisis shock higher real wage rigidity increases redistribution towards workers, although both groups suffer a larger income loss in absolute terms. Essentially, less flexible wages amplify the negative impact on investment and growth since firms' scope for reducing production costs is more limited, resulting in stronger reductions in profits and thereby larger falls in asset prices. The fall in asset prices makes the collateral constraint more binding, leading to a larger decline in borrowing and investment which in turn amplifies the reduction in the income of capital holders. Since the response of wages is muted, the response to the crisis results in a larger drop in hours worked, thereby also affecting workers. Under a positive inflation shock, lower real wage flexibility amplifies redistribution towards capital holders. As the collateral constraint is relaxed with rising nominal asset prices, rising borrowing and investment increase labour demand and the equilibrium wage level. Under higher wage rigidity, this rise in labour demand results in slower wage increases, and hence in a smaller increase in production costs. This effect dominates the rise in labour income that results from a stronger positive response in hours worked which boosts workers' income. In a similar vein, in the case of a positive productivity shock, lower wage flexibility - while benefiting both capital holders and workers amplifies redistribution in favour of capital holders. As for the inflation shock, this is because higher real wage rigidity slows down the adjustment of wages to the equilibrium level implied by the higher productivity level.

\section{Conclusion}

45. This paper employs a tractable DSGE framework to explore the distributive impact of macroeconomic shocks, and how it is shaped by selected institutions. It shows that financial crises redistribute in relative terms from equity to bond holders, as well as from capital to labour. In contrast, both inflation and productivity shocks redistribute in the opposite directions. Under the plausible assumption that workers or bond holders have lower incomes than capital holders, financial crises would reduce income inequality in the short- to medium term, whereas productivity and inflation shocks would increase it.

46. The institutional analysis shows that more sophisticated financial markets amplify the redistributive impact of shocks, as do a less elastic labour supply and more rigid real wages. In contrast, a more reactive central bank or more regulated product markets dampen shock-driven redistribution. Consequently, in the presented framework a given institution can have positive or negative effects on income inequality depending on the type of shock an economy is subjected to. For example, higher real wage rigidity (reflecting more regulated labour markets) leads to short- and medium-term reductions in income inequality in the wake of financial crises, but to increases following productivity or inflation shocks.

47. While the use of two groups of agents presents an important enrichment of standard DSGE analysis, the distributional implications of shocks may be even more complex in reality. The presented inequality results could hence depend on the specific two-group framework, pointing to the need for further differentiating agents in future redistribution-oriented DSGE work. Also, this paper possibly 


\section{ECO/WKP(2011)53}

pioneers the use of a DSGE framework for exploring the role of institutions in shaping distributional outcomes in the wake of shocks. The remaining wide array of institutions and shocks that it cannot cover present ample opportunities for future work. One interesting direction may be to study the distributional implications of labour market institutions in more detail, e.g. by introducing heterogeneous agents into labour market set-ups with search frictions. ${ }^{20}$

20. For a model with a more developed labour market see e.g. Cacciatore and Fiori (2011). 


\section{REFERENCES}

Ahrend, R., Arnold, J. and C. Moeser (2011). "The Sharing of Macroeconomic Risk: Who Loses (and Gains) from Macroeconomic Shocks”, OECD Economics Department Working Papers, No. 877.

Arnold, J., Nicoletti, G. and S. Scarpetta (2008). "Product Market Policies, Allocative Efficiency and Productivity: A Cross-Country Analysis" OECD Economics Department Working Papers, No. 616.

Bernanke, B., and M. Gertler (1997), "Agency Costs, Net Worth, and Business Fluctuations", American Economic Review, No. 79(1).

Bacchetta, P. and R. Caminal (2000), "Do Capital Market Imperfections Exacerbate Output Fluctuations?", European Economic Review, No. 44.

Blanchard, O. and J. Gali (2007), "Real Wage Rigidities and the New Keynesian Model ", Journal of Money, Credit, and Banking, No. 39.

Bourlès, R., G. Cette, L. Lopez, J. Mairesse and G. Nicoletti (2010), "Do Product Market Regulations in Upstream Sectors Curb Productivity Growth?: Panel Data Evidence for OECD Countries", OECD Economics Department Working Papers, No. 791.

Cacciatore, M. and G. Fiori (2011), "Macroeconomic Effects of (De)Regulation: The Long and Short of Reforming Europe", Boston College, Working Papers, forthcoming.

Calza, A., T. Monacelli and L. Stracca (2010), "Housing Finance and Monetary Policy", ECB Working Paper, No. 1069, European Central Bank.

Curdia, V. and M. Woodford (2009), "Credit Frictions and Optimal Monetary Policy", Federal Reserve Bank of New York and Columbia University.

Curdia, V. and M. Woodford (2010), "Credit Spreads and Monetary Policy", Journal of Money Credit and Banking, No. 42.

De Fiore, F., and O. Tristani (2007), "Credit and the Natural Rate of Interest", ECB Working Paper Series, No. 889, European Central Bank.

Doepke, M., and M. Schneider (2006a), "Inflation as a Redistribution Shock: Effects on Aggregates and Welfare", NBER Working Paper, No. W12319.

Doepke, M., and M. Schneider (2006b), "Inflation and the Redistribution of Nominal Wealth", Journal of Political Economy, No. 114(6).

Faia, E. and T. Monacelli (2008). "Optimal Monetary Policy in A Small Open Economy with Home Bias", Journal of Money, Credit and Banking, Vol. 40.

Fisher, I. (1933), "The Debt-Deflation Theory of Great Depressions", Econometrica, No. 1(4). 
ECO/WKP(2011)53

Goodfriend, M., and B. McCallum (2007), "Banking and Interest Rates in Monetary Policy Analysis: A Quantitative Exploration", Journal of Monetary Economics, No. 54.

Iacoviello, M. (2005), "House Prices, Borrowing Constraints, and Monetary Policy in the Business Cycle", American Economic Review, No. 95.

Kiyotaki, N., and J. Moore (1997), "Credit Cycles", Journal of Political Economy, No. 105(2).

Monacelli, T. (2009), "New Keynesian Models, Durable Goods, and Collateral Constraints", Journal of Monetary Economics, No. 56(2).

Nolan, C., and C. Thoenissen (2009), "Financial Shocks and the U.S. Business Cycle", Journal of Monetary Economics, No. 56(4).

Rotemberg, J. (1982). "Monopolistic price adjustment and aggregate output", The Review of Economic Studies, Vol. 49. 
ANNEX

Table 1. Synthesis of modelling results

\begin{tabular}{|l|l|l|l|l|}
\hline \multirow{2}{*}{} & \multicolumn{2}{|c|}{ Baseline Model } & \multicolumn{2}{c|}{ Extended Model } \\
\cline { 2 - 5 } & Bond holders & Equity holders & Workers & Capital holders \\
\hline Shocks & Moderate gains & Strong losses & Small gains & Strong losses \\
\hline $\begin{array}{l}\text { Financial crisis } \\
\text { shock }\end{array}$ & Moderate losses & Strong gains & Small losses & Strong gains \\
\hline Inflation shock & Strong gains & Moderate gains & Strong gains \\
\hline $\begin{array}{l}\text { Productivity shock } \\
\text { Small gains }\end{array}$ & Greater financial market sophistication amplifies the redistributive impact of all shocks. \\
\hline $\begin{array}{l}\text { Institutions } \\
\text { sophistication }\end{array}$ & Stronger central bank responsiveness dampens the redistributive impact of all shocks. \\
\hline $\begin{array}{l}\text { Central bank } \\
\text { responsiveness }\end{array}$ & & $\begin{array}{l}\text { A less elastic labour supply amplifies the } \\
\text { redistributive impact of all shocks. }\end{array}$ \\
\hline $\begin{array}{l}\text { Labour supply } \\
\text { elasticity }\end{array}$ & $\begin{array}{l}\text { Product market } \\
\text { regulation }\end{array}$ & $\begin{array}{l}\text { More regulated product markets dampen } \\
\text { the redistributive impact of all shocks. }\end{array}$ \\
\hline redistributive impact of all shocks. \\
\hline
\end{tabular}


Figure 1. Financial crisis shock

Basic model: nominal bond holders versus real equity holders
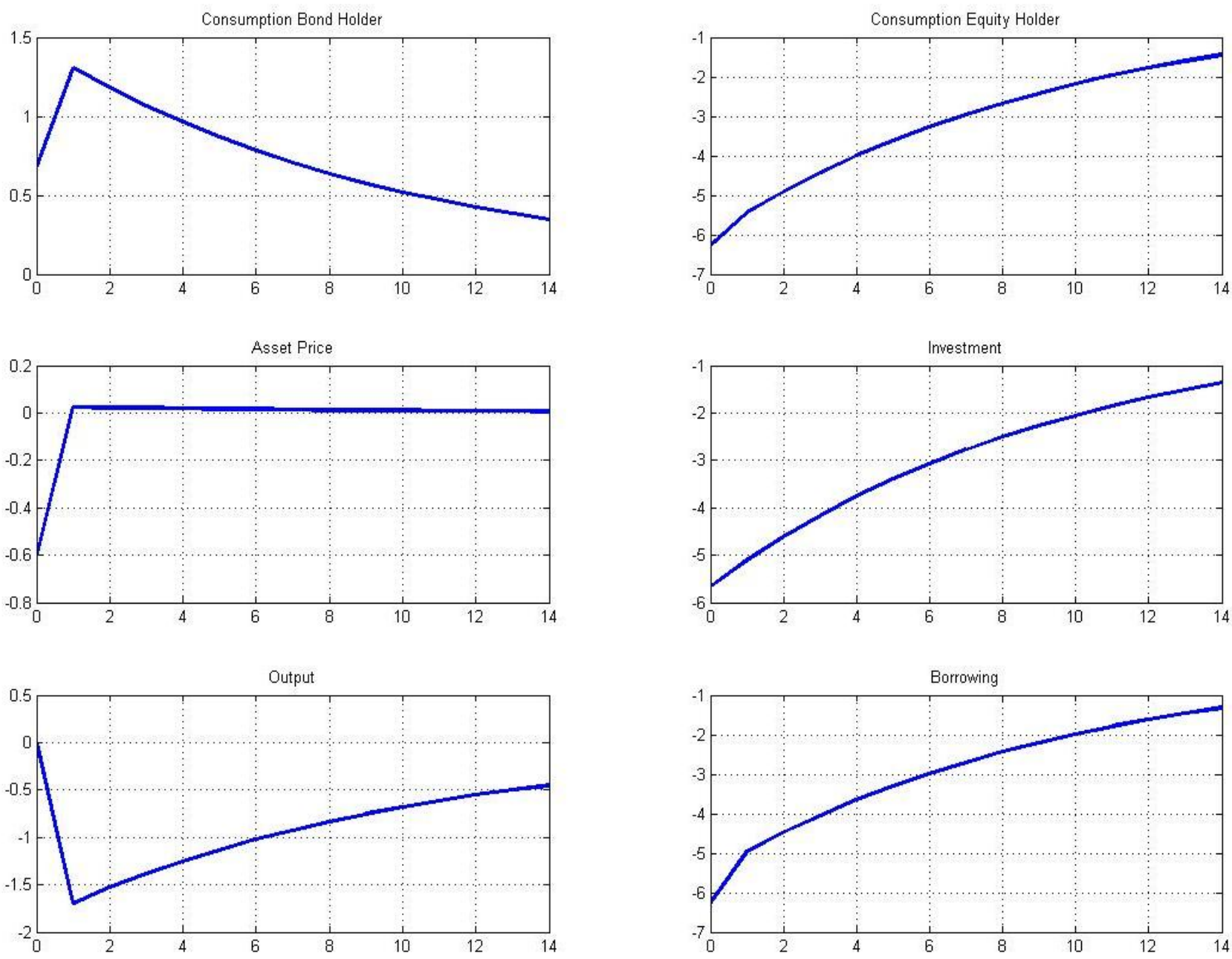
Figure 2. Inflation shock

Basic model: nominal bond holders versus real equity holders
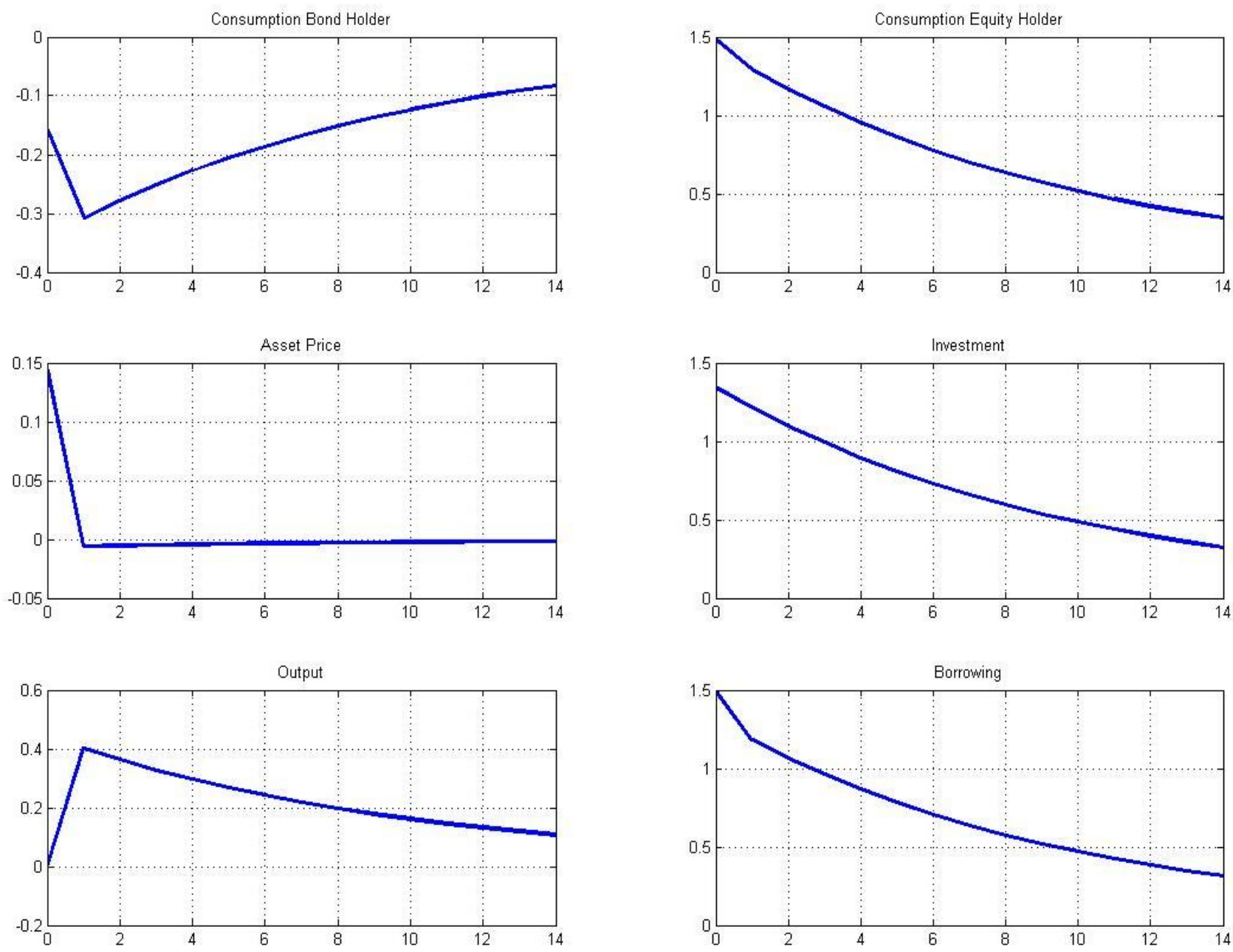
Figure 3. Productivity shock

Basic model: nominal bond holders versus real equity holders
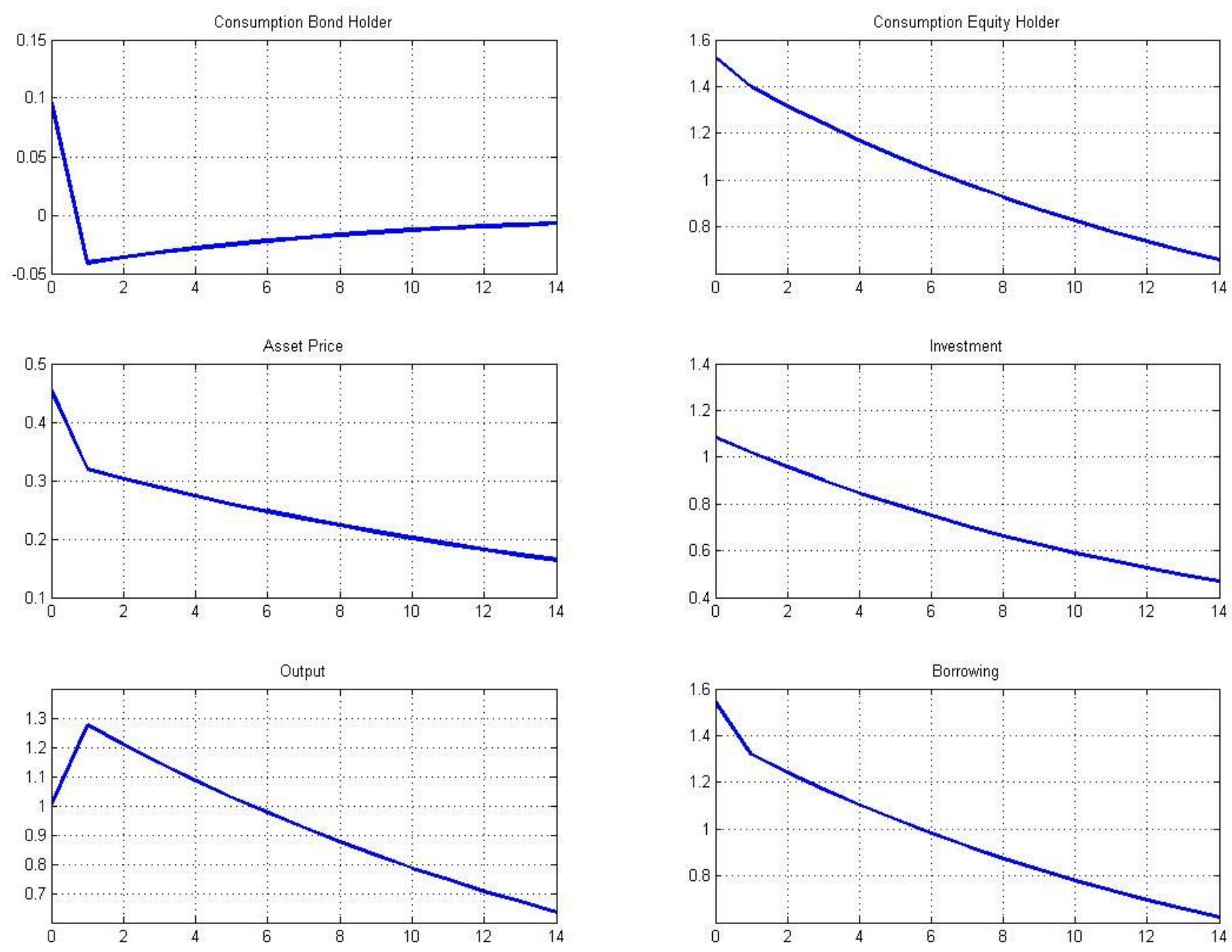
Figure 4. Financial crisis shock under different levels of financial market sophistication

Basic model: nominal bond holders versus real equity holders
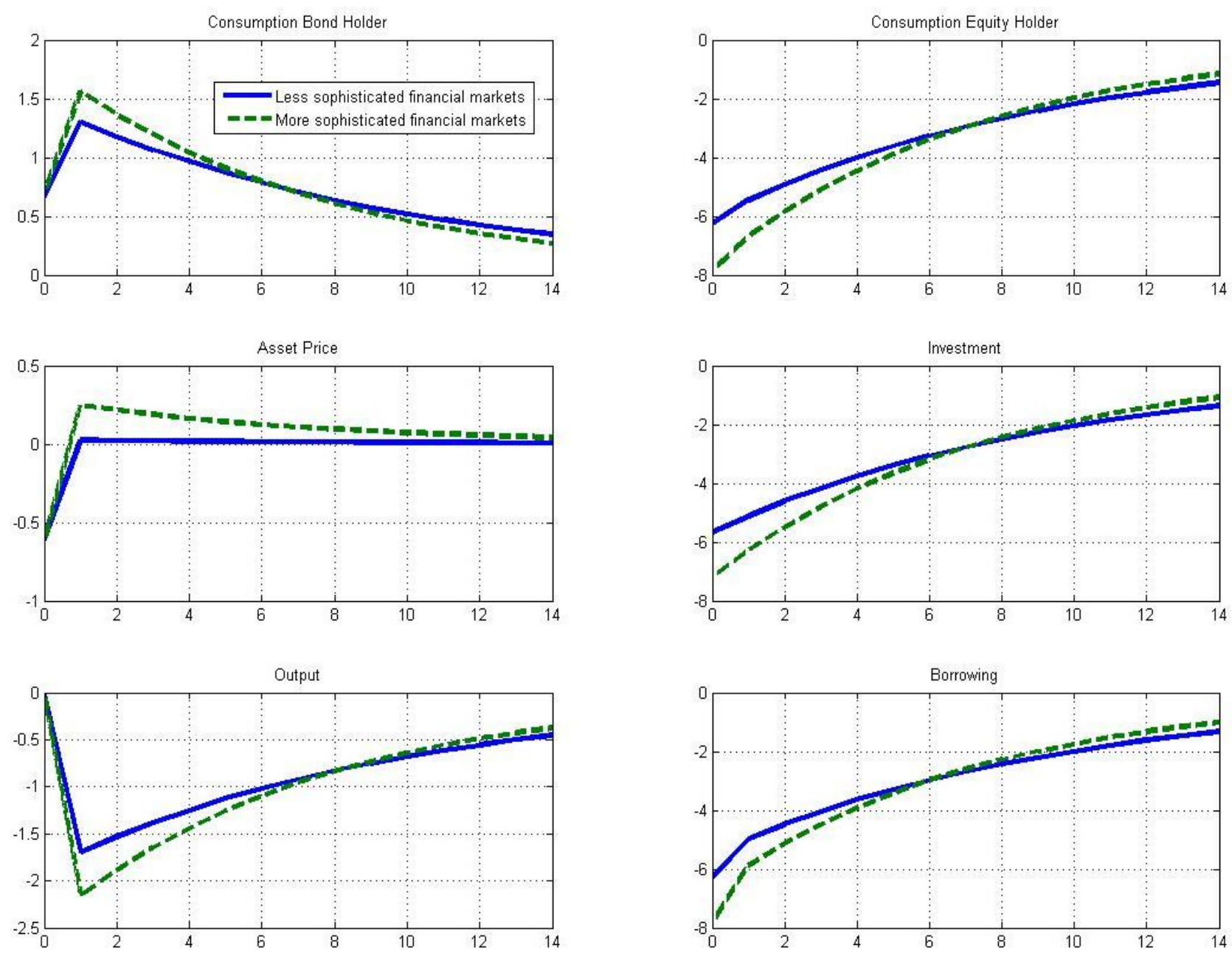
Figure 5. Inflation shock under different levels of financial market sophistication

Basic model: nominal bond holders versus real equity holders
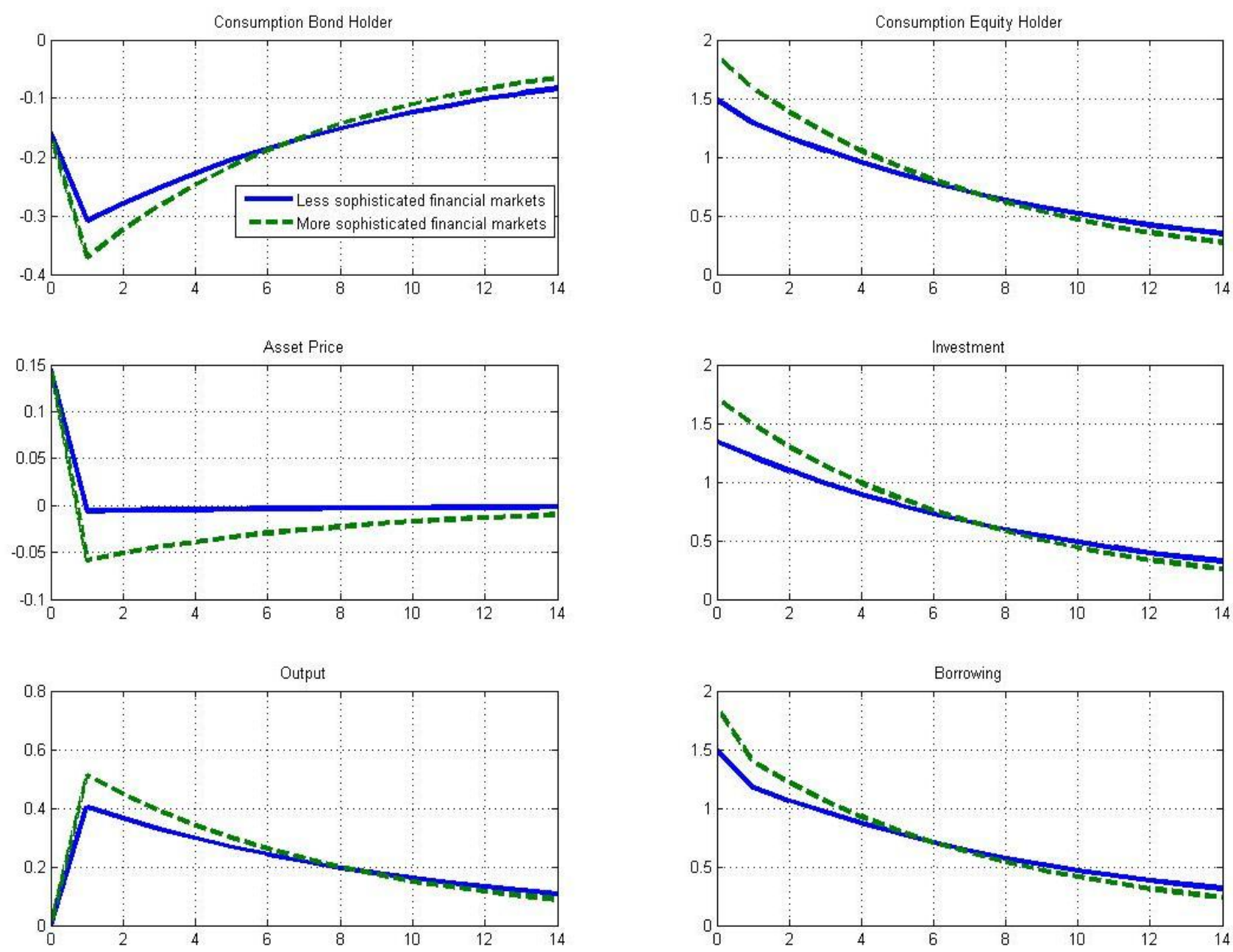
Figure 6. Productivity shock under different levels of financial market sophistication

Basic model: nominal bond holders versus real equity holders
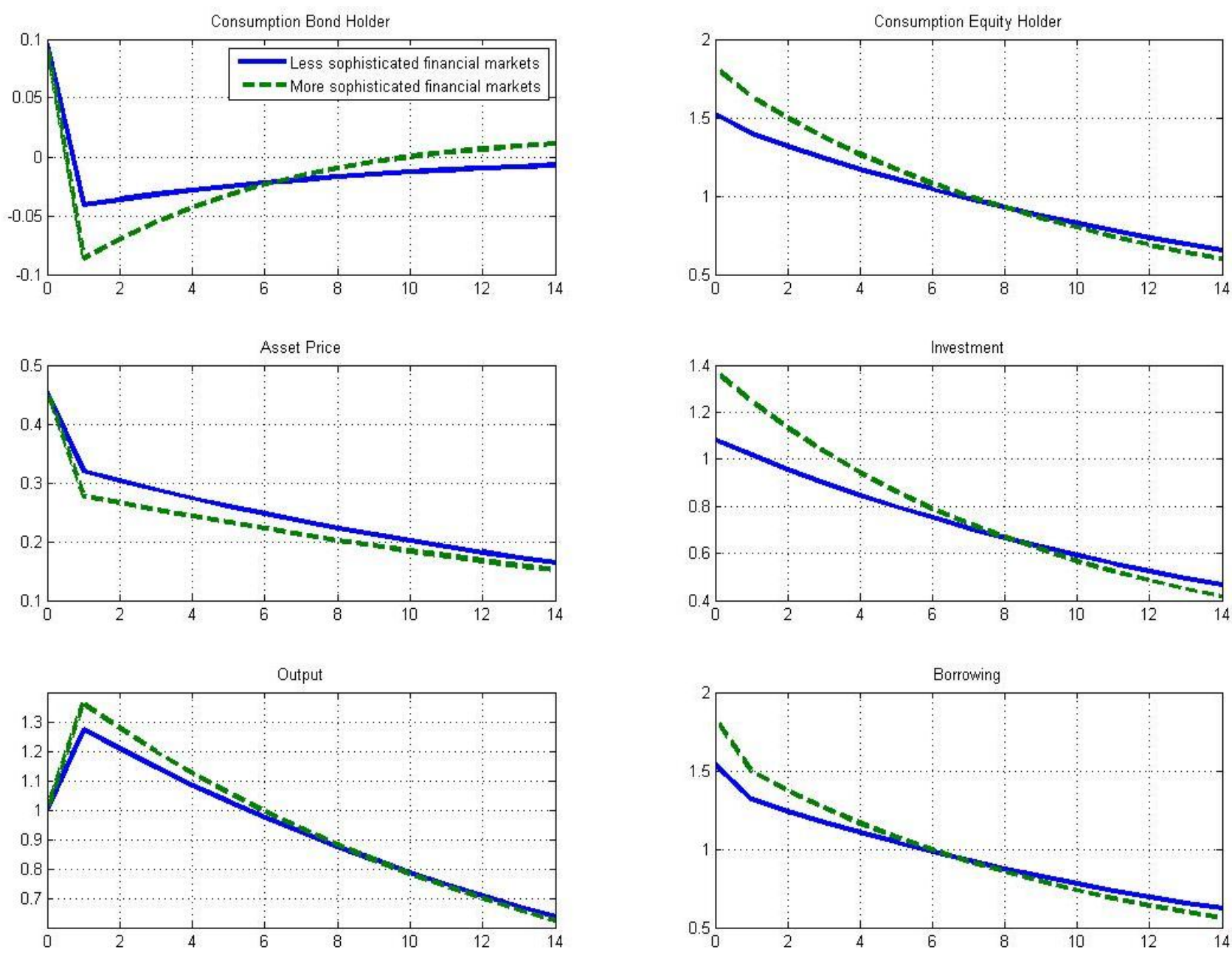
Figure 7. Financial crisis shock under different central bank reaction functions

Basic model: nominal bond holders versus real equity holders
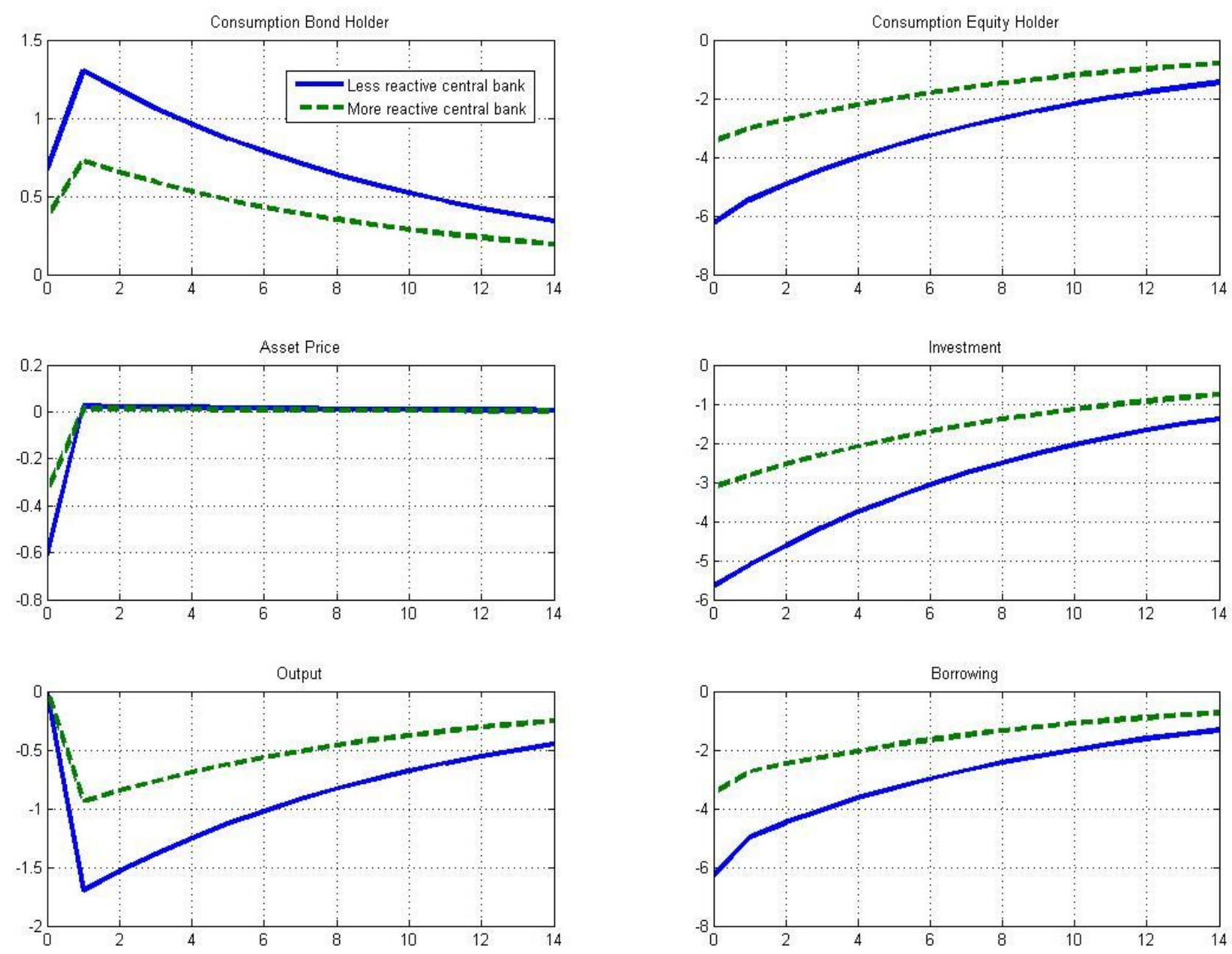
Figure 8. Inflation shock under different central bank reaction functions

Basic model: nominal bond holders versus real equity holders
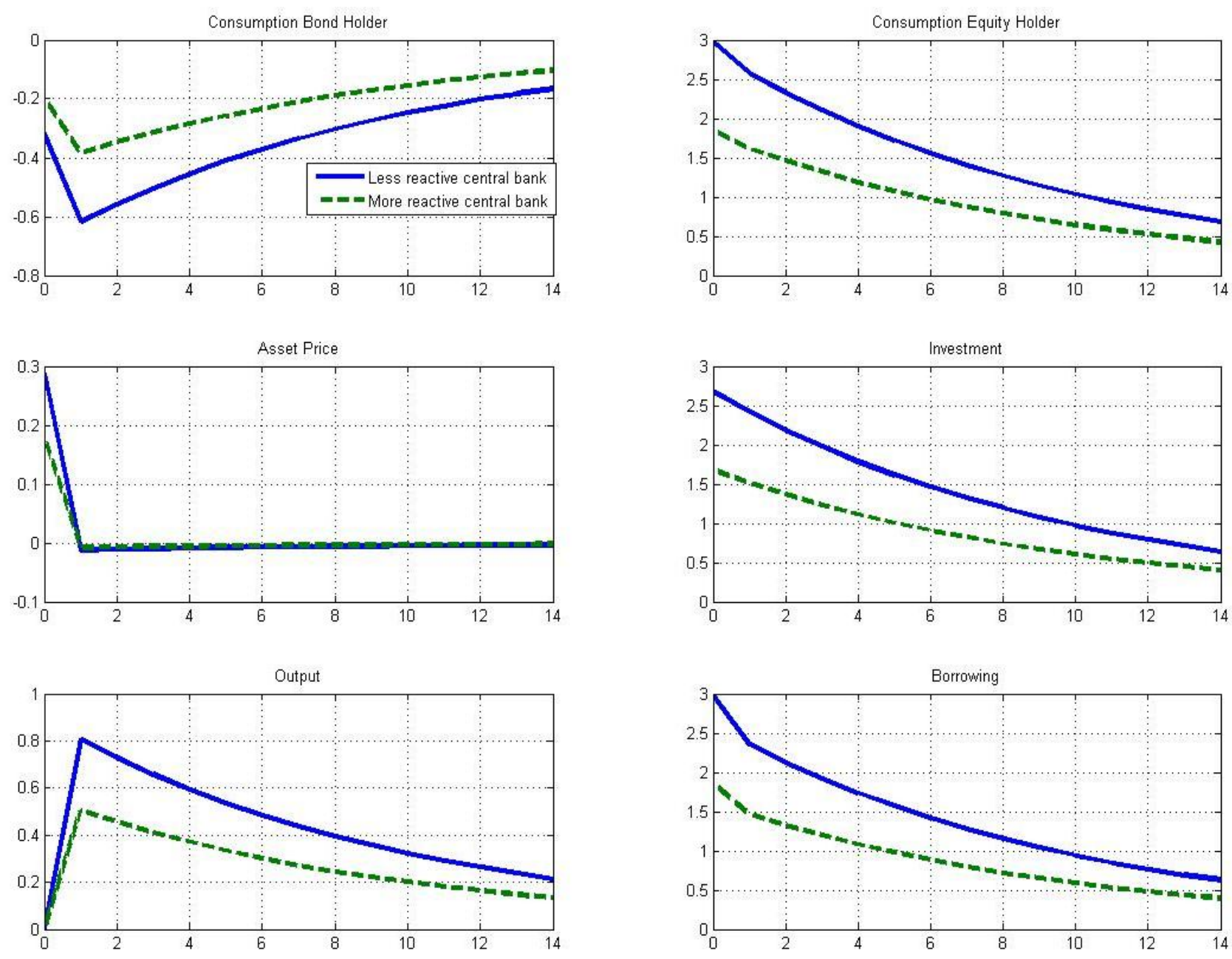
Figure 9. Financial crisis shock

Extended model: capital owners versus workers
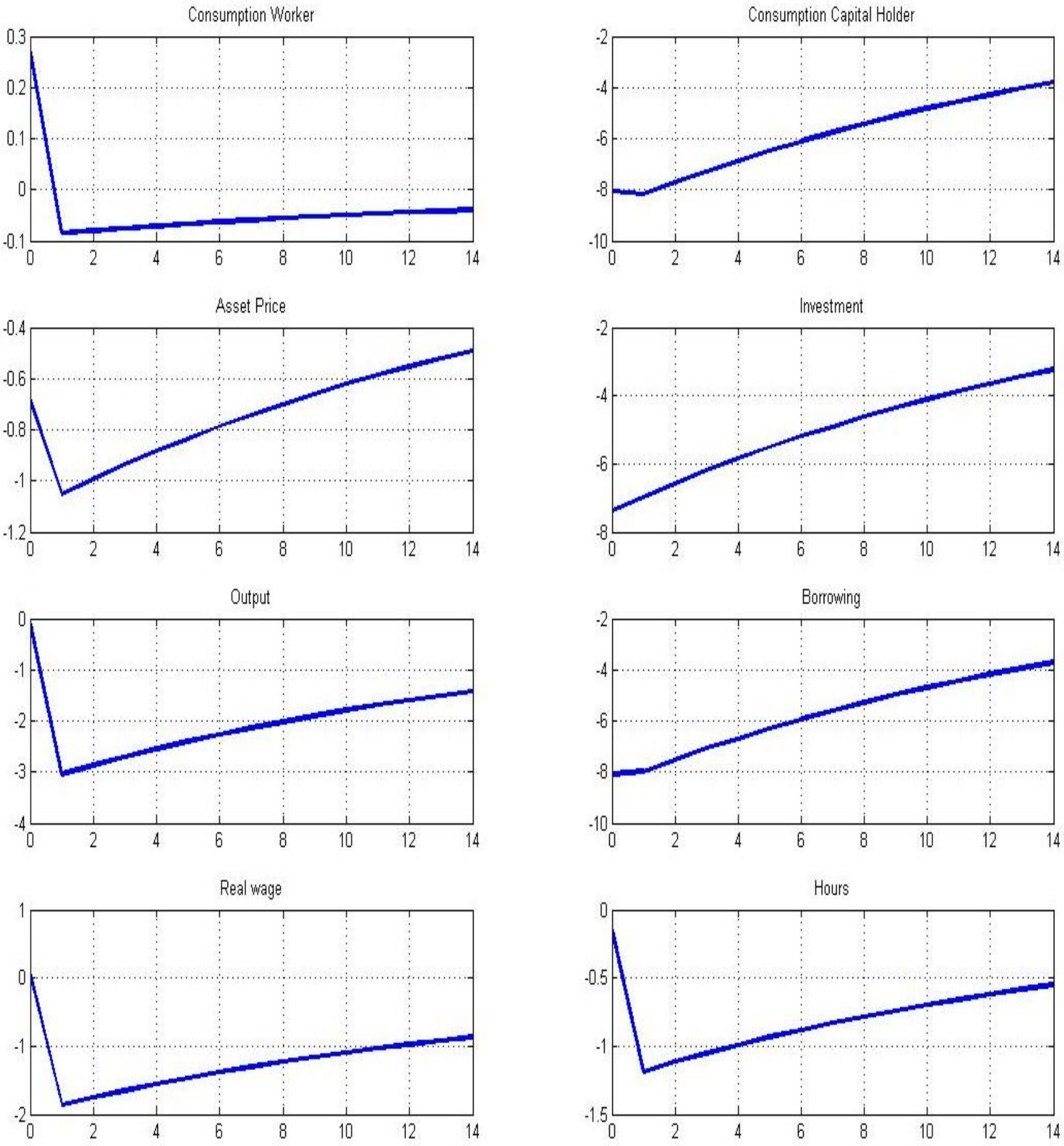
Figure 10. Inflation shock

Extended model: capital owners versus workers
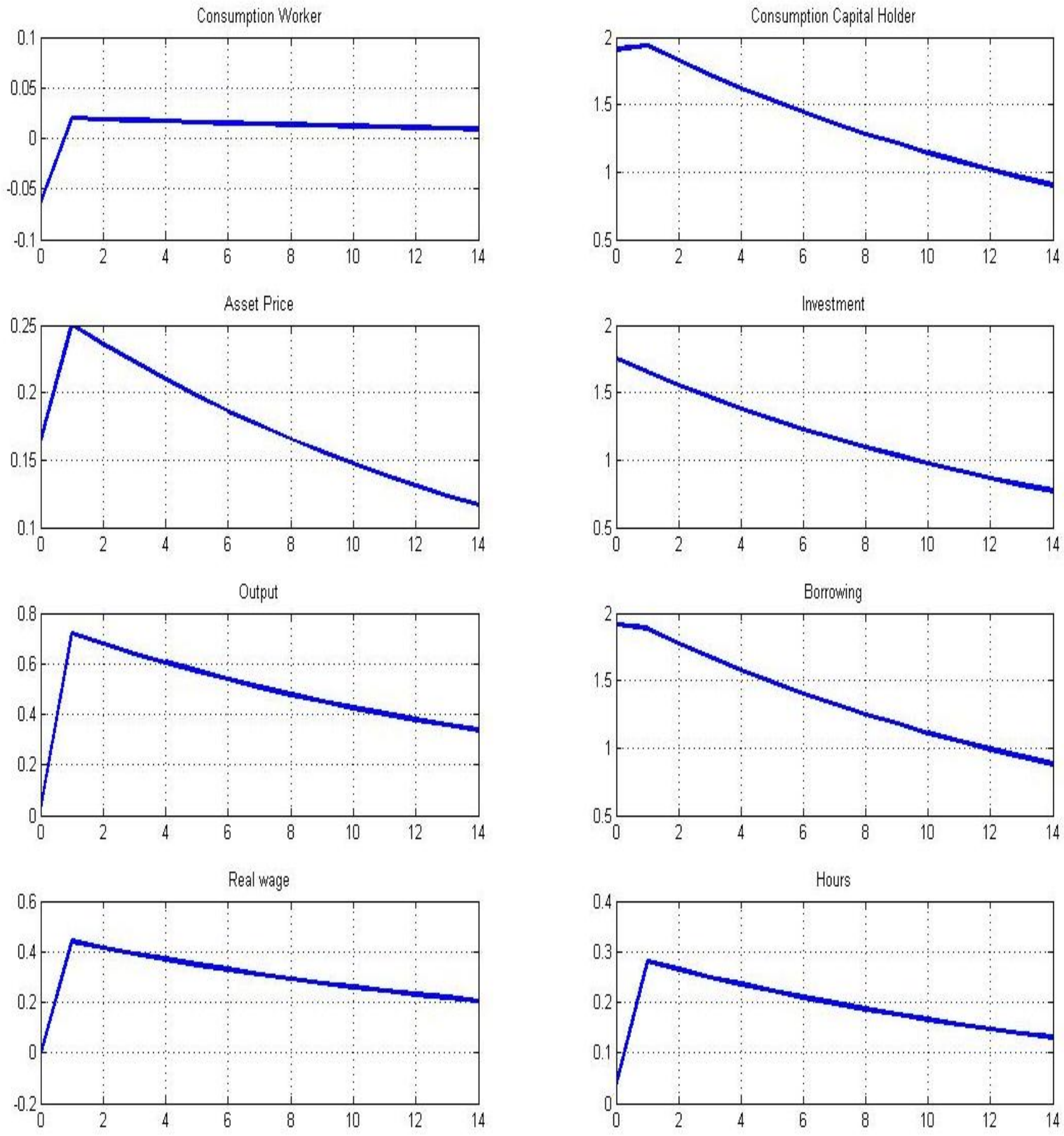
Figure 11. Productivity shock

Extended model: capital owners versus workers
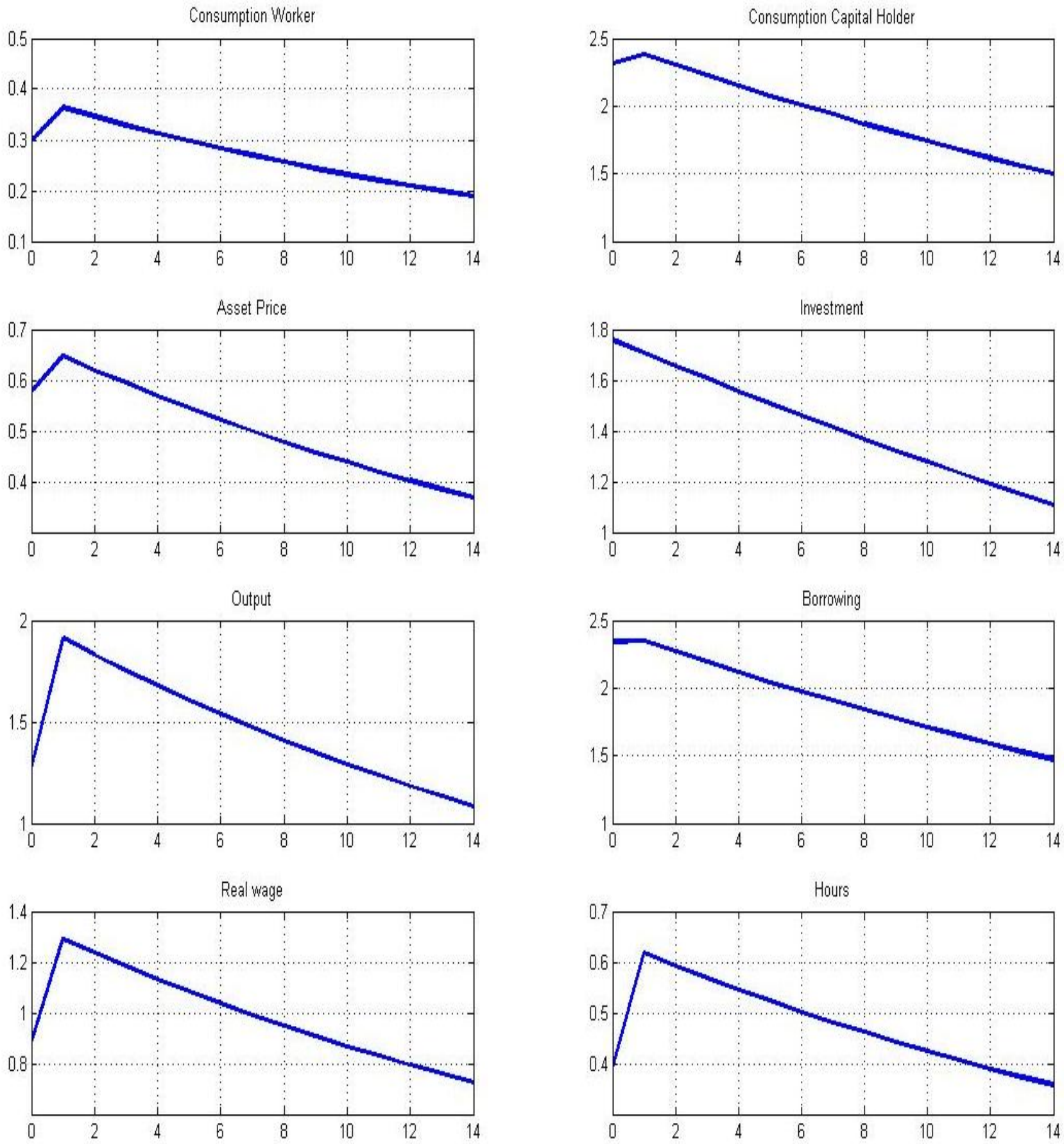
Figure 12. Financial crisis shock under different levels of financial market sophistication Extended model: capital owners versus workers
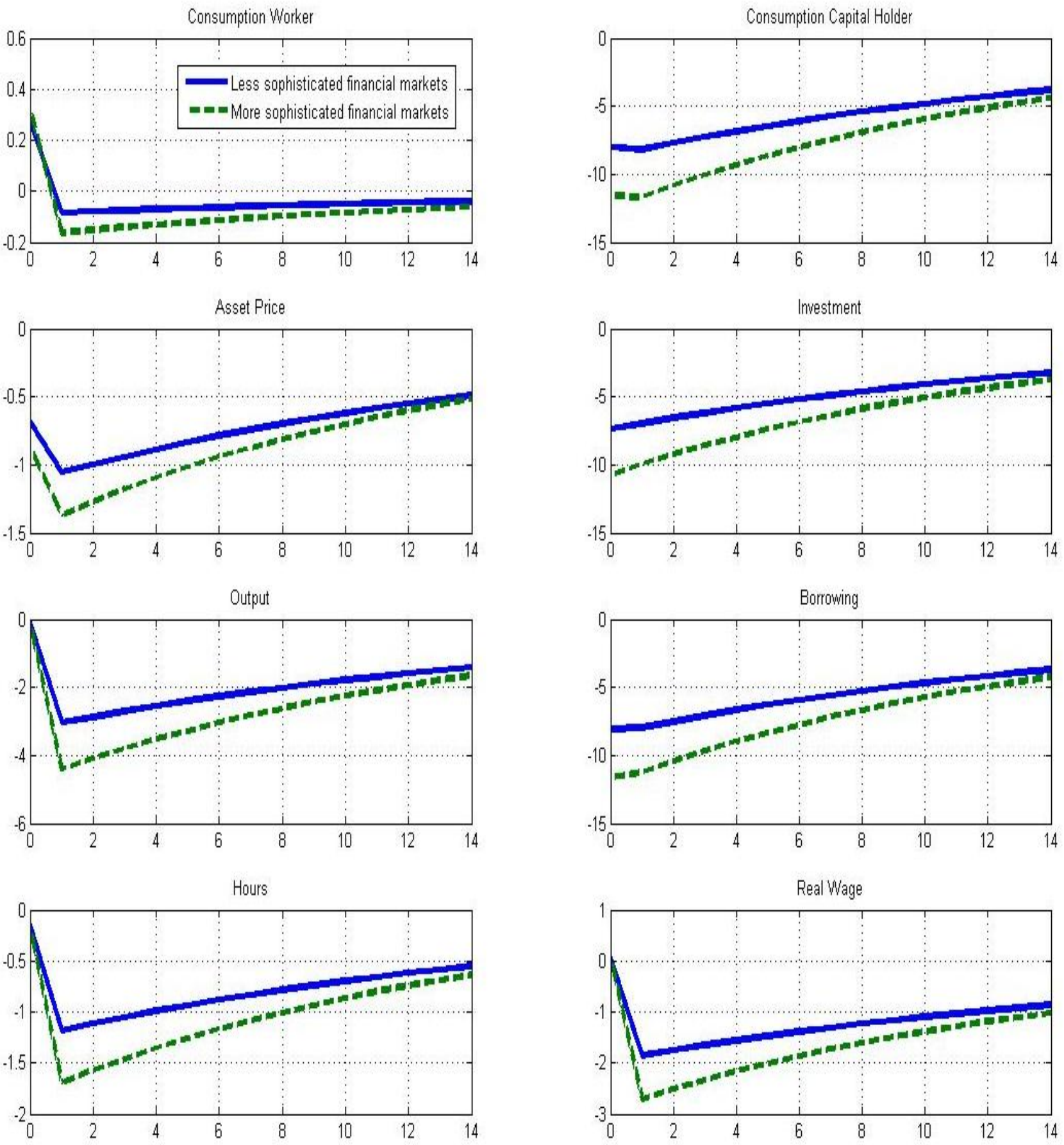
Figure 13. Inflation shock under different levels of financial market sophistication

Extended model: capital owners versus workers
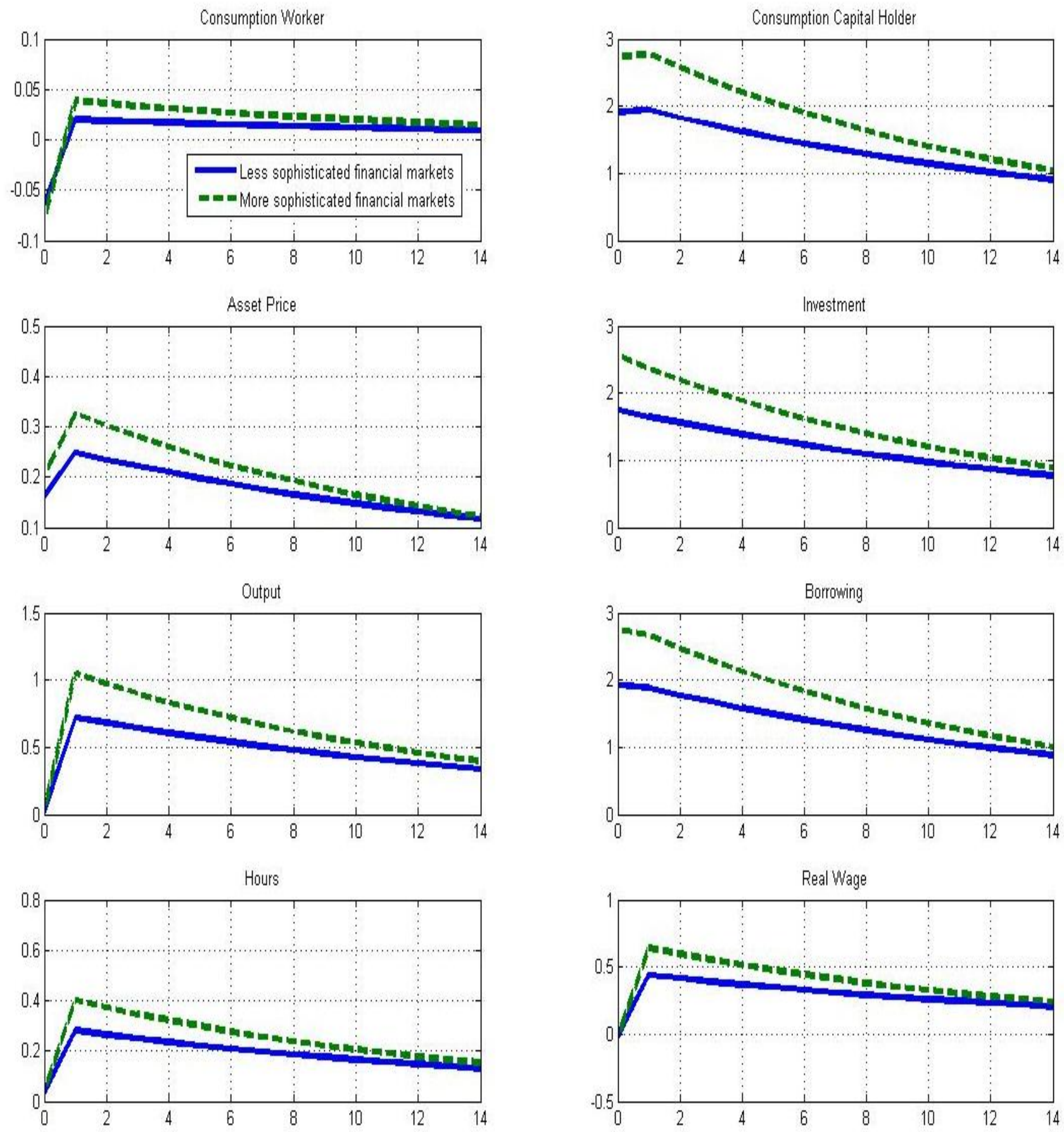
Figure 14. Productivity shock under different levels of financial market sophistication Extended model: capital owners versus workers
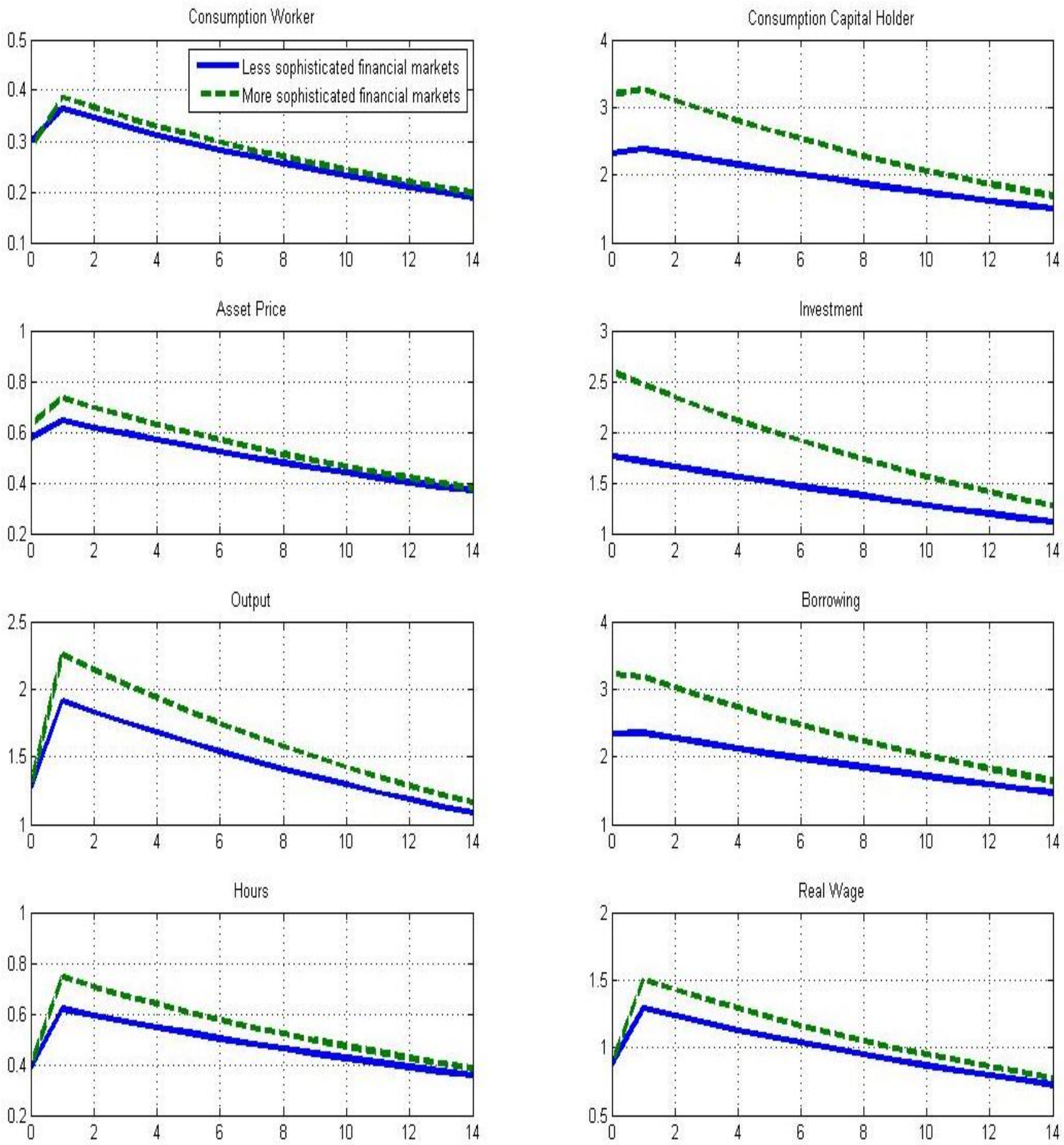
Figure 15. Financial crisis shock under different central bank reaction functions Extended model: capital owners versus workers
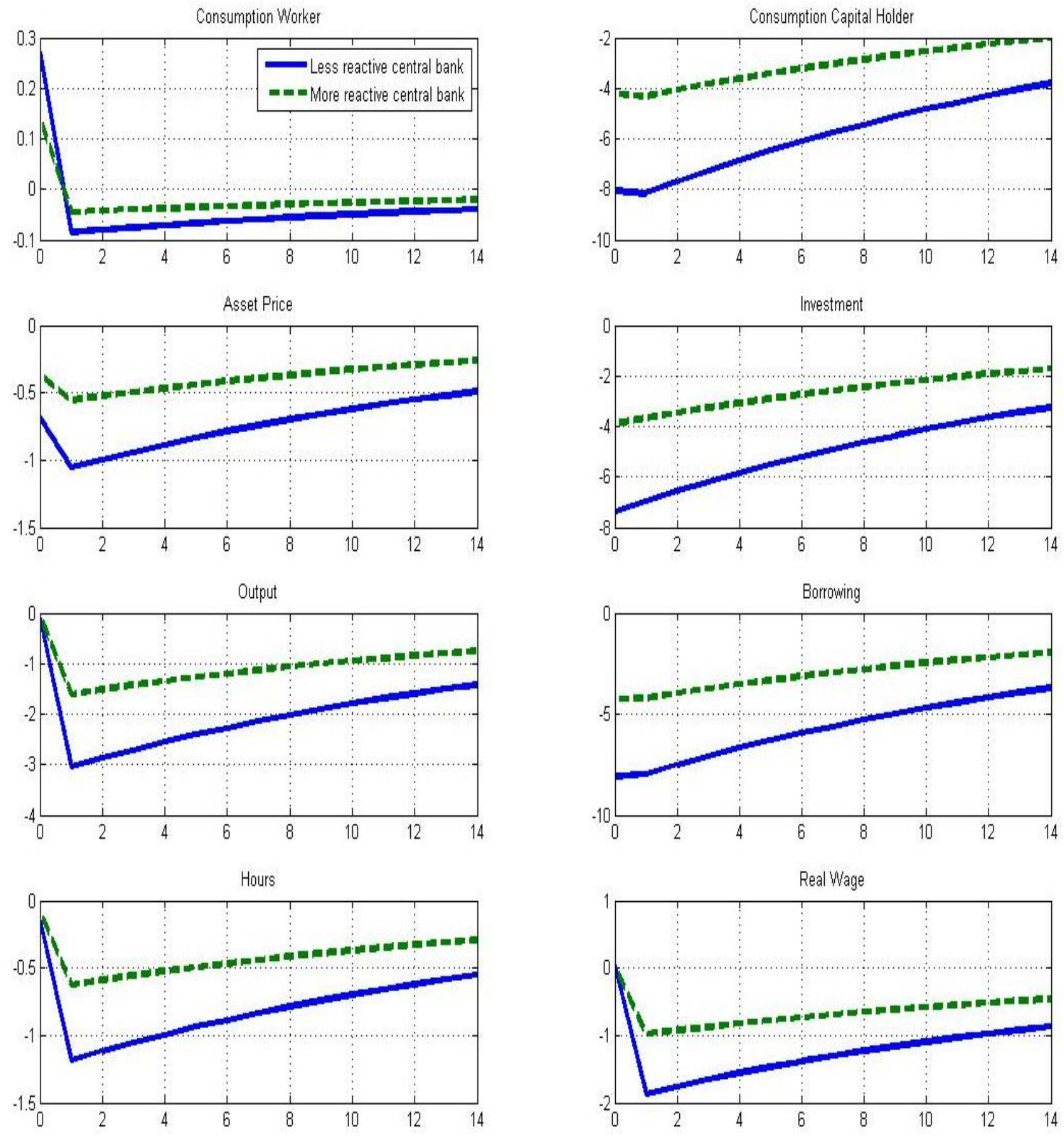
Figure 16. Inflation shock under different central bank reaction functions

Extended model: capital owners versus workers
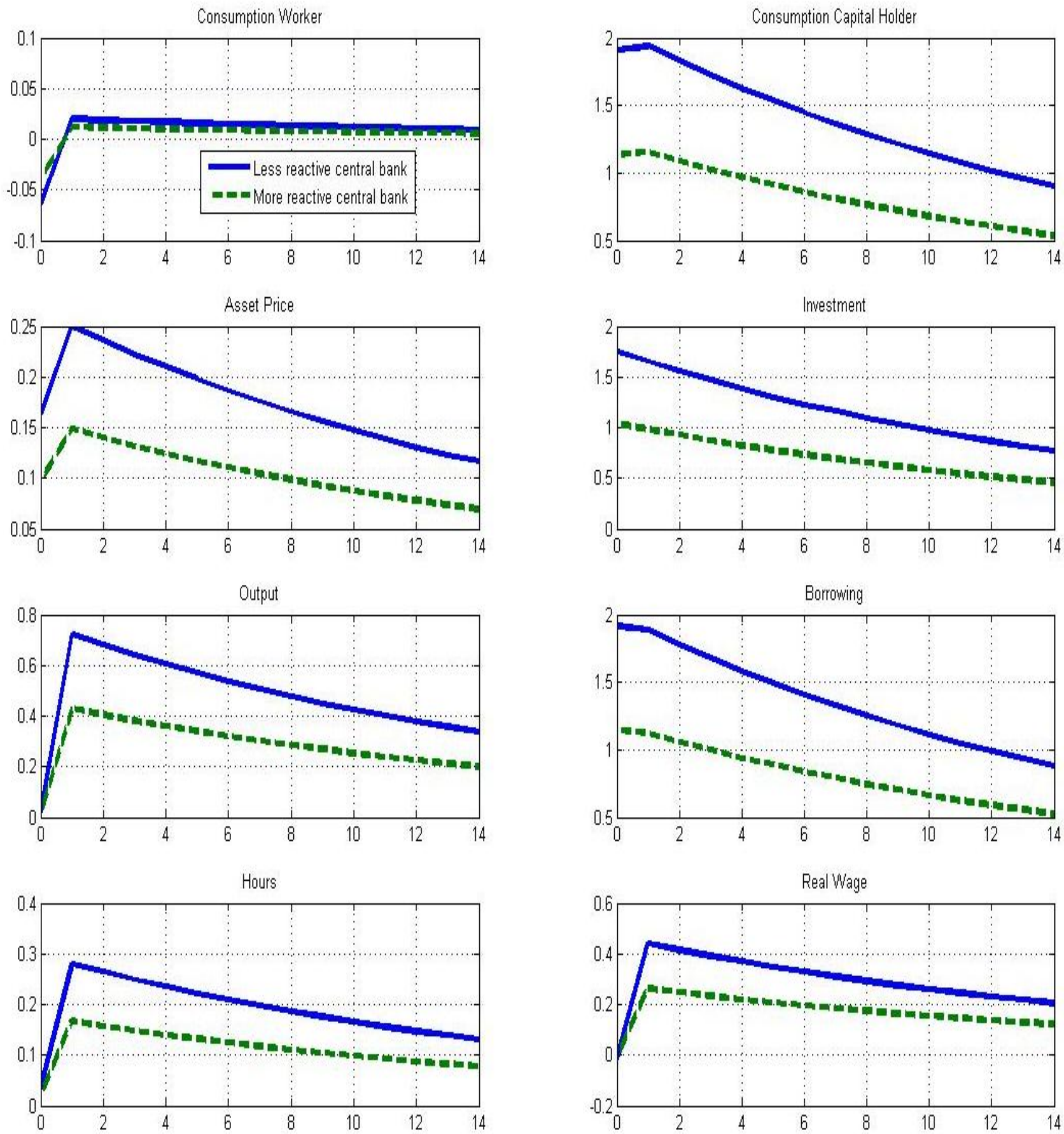
Figure 17. Financial crisis shock under different labour supply elasticities

Extended model: capital owners versus workers
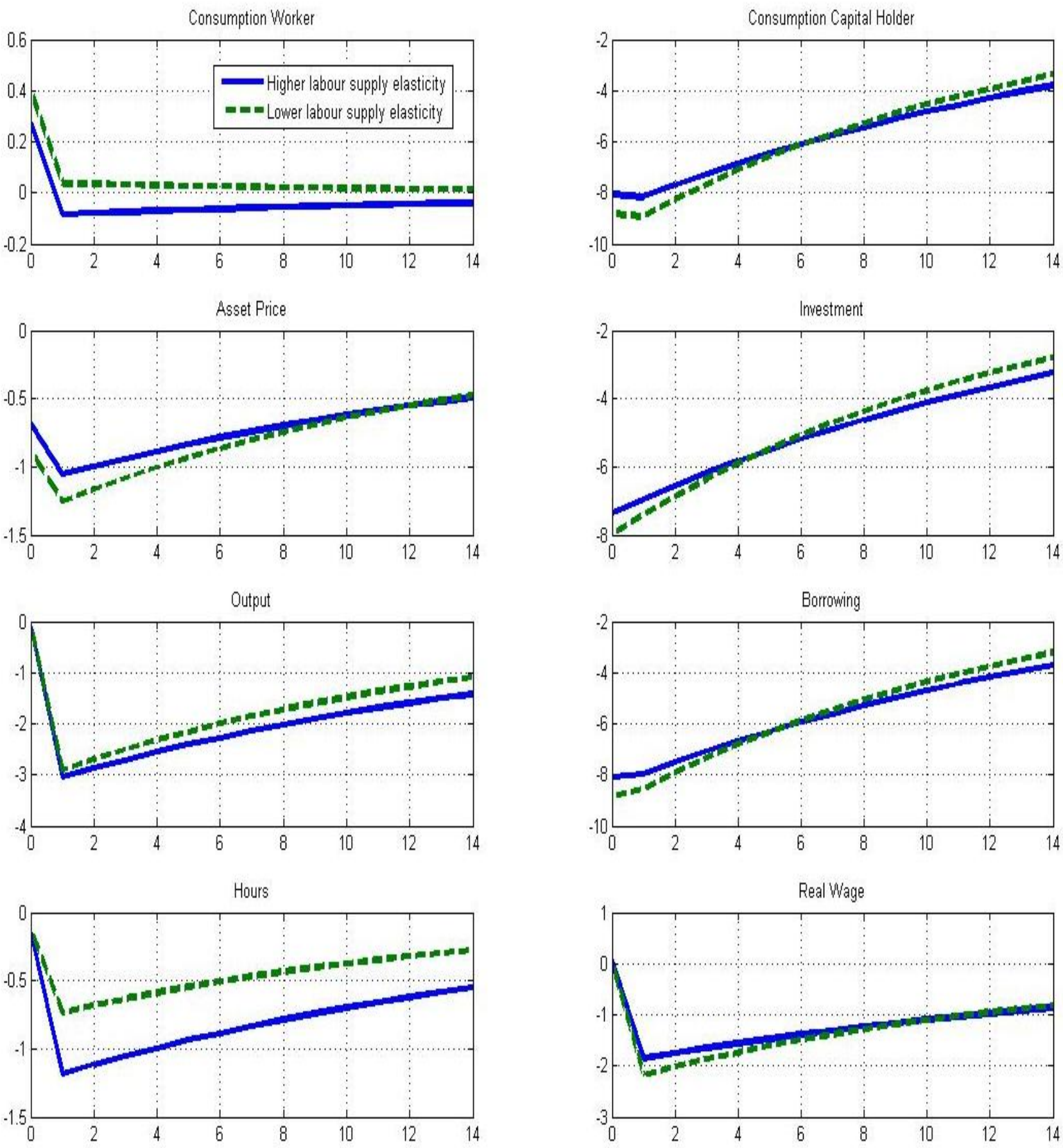
Figure 18. Inflation shock under different labour supply elasticities

Extended model: capital owners versus workers
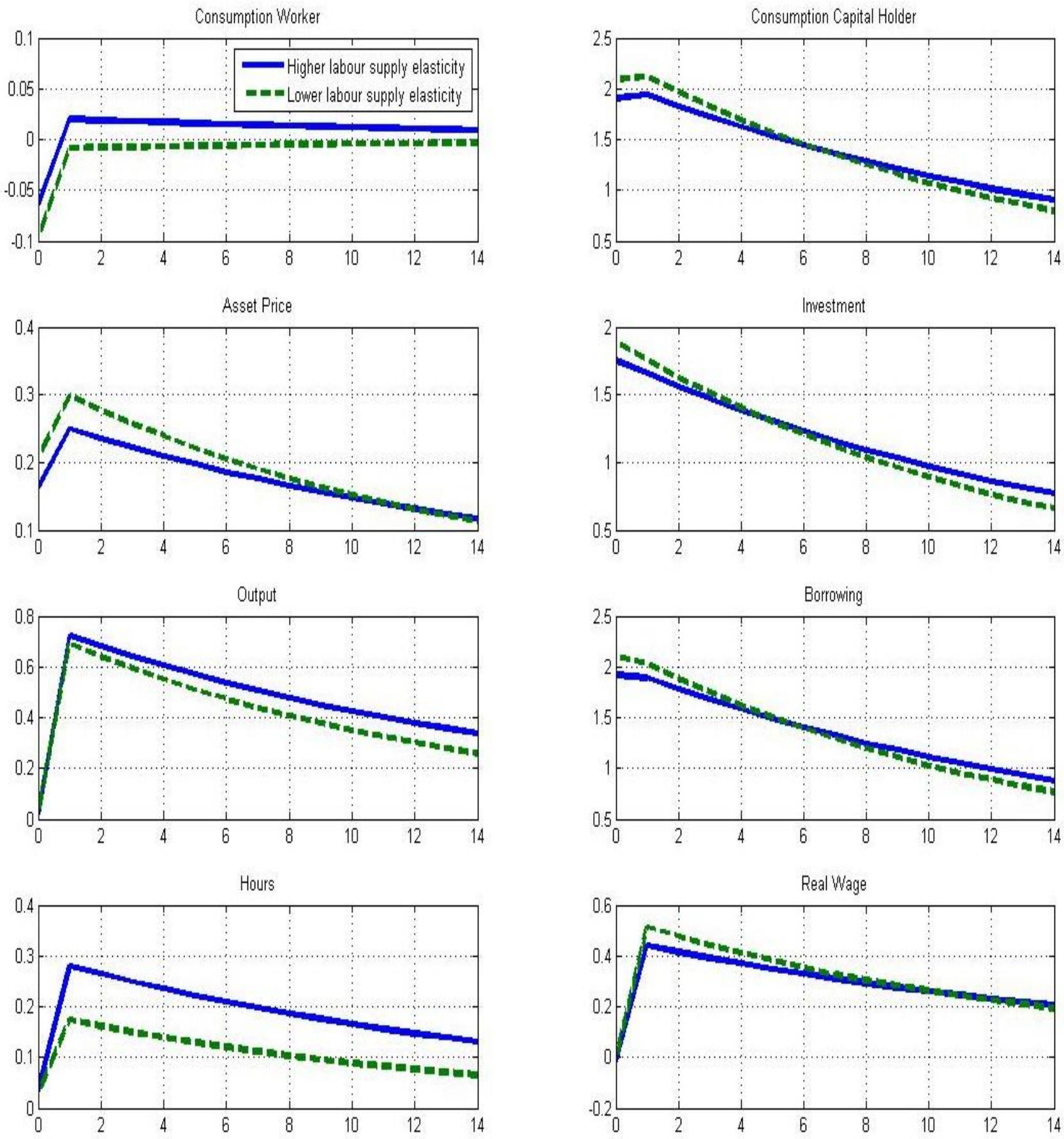
Figure 19. Productivity shock under different labour supply elasticities

Extended model: capital owners versus workers
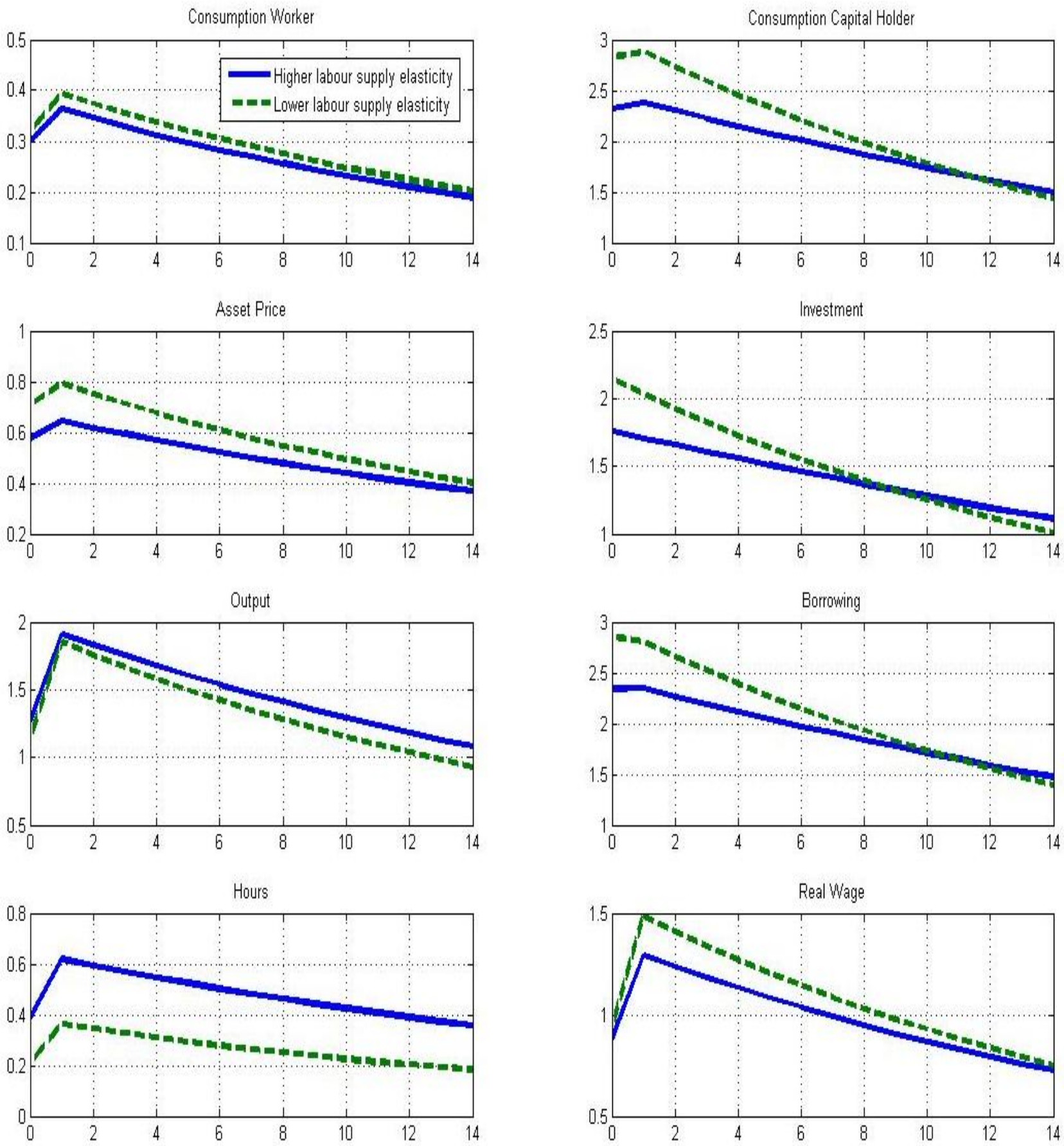
Figure 20. Financial crisis shock under different degrees of PMR

Extended model: capital owners versus workers
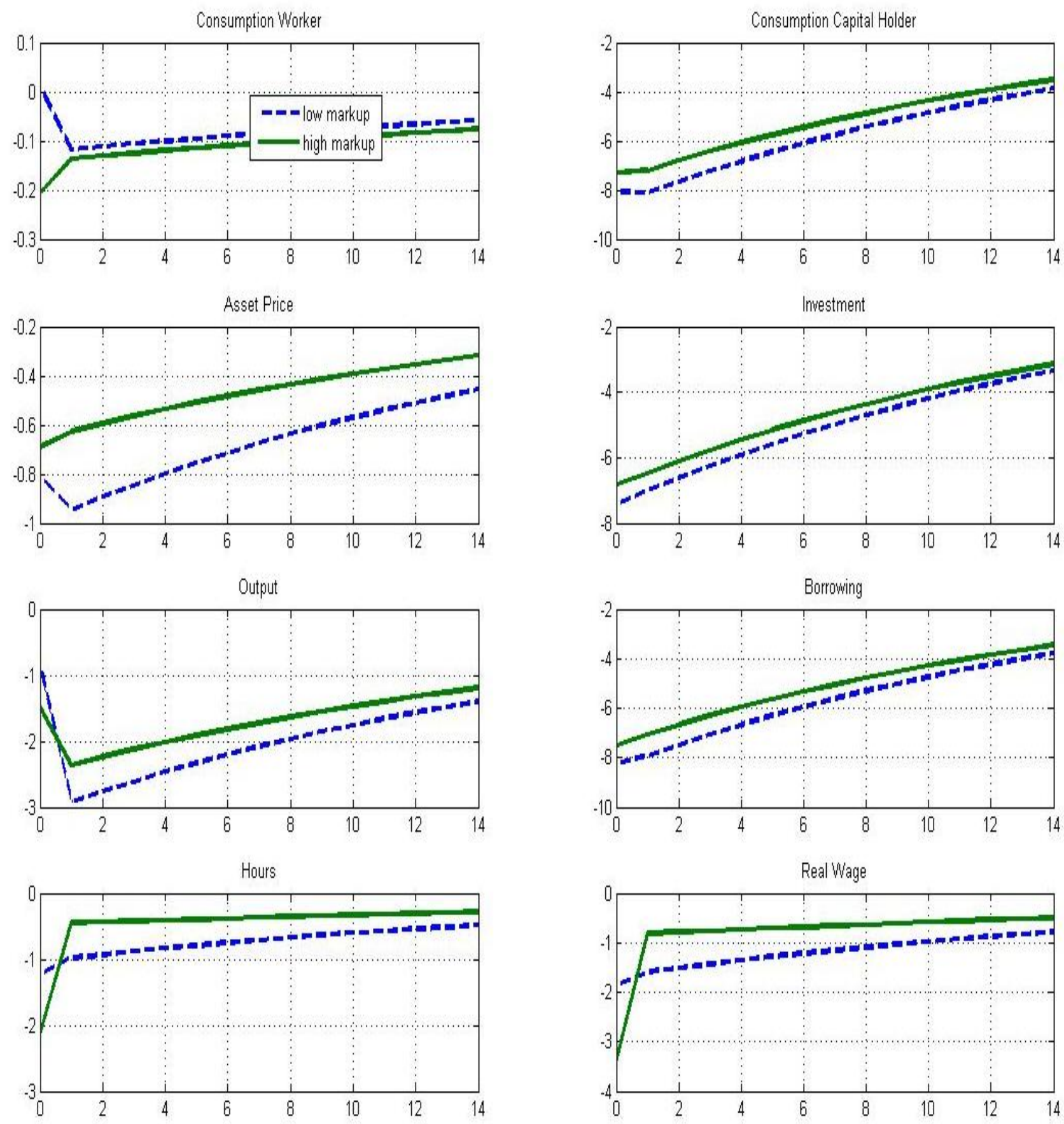
Figure 21. Inflation shock under different degrees of PMR

Extended model: capital owners versus workers
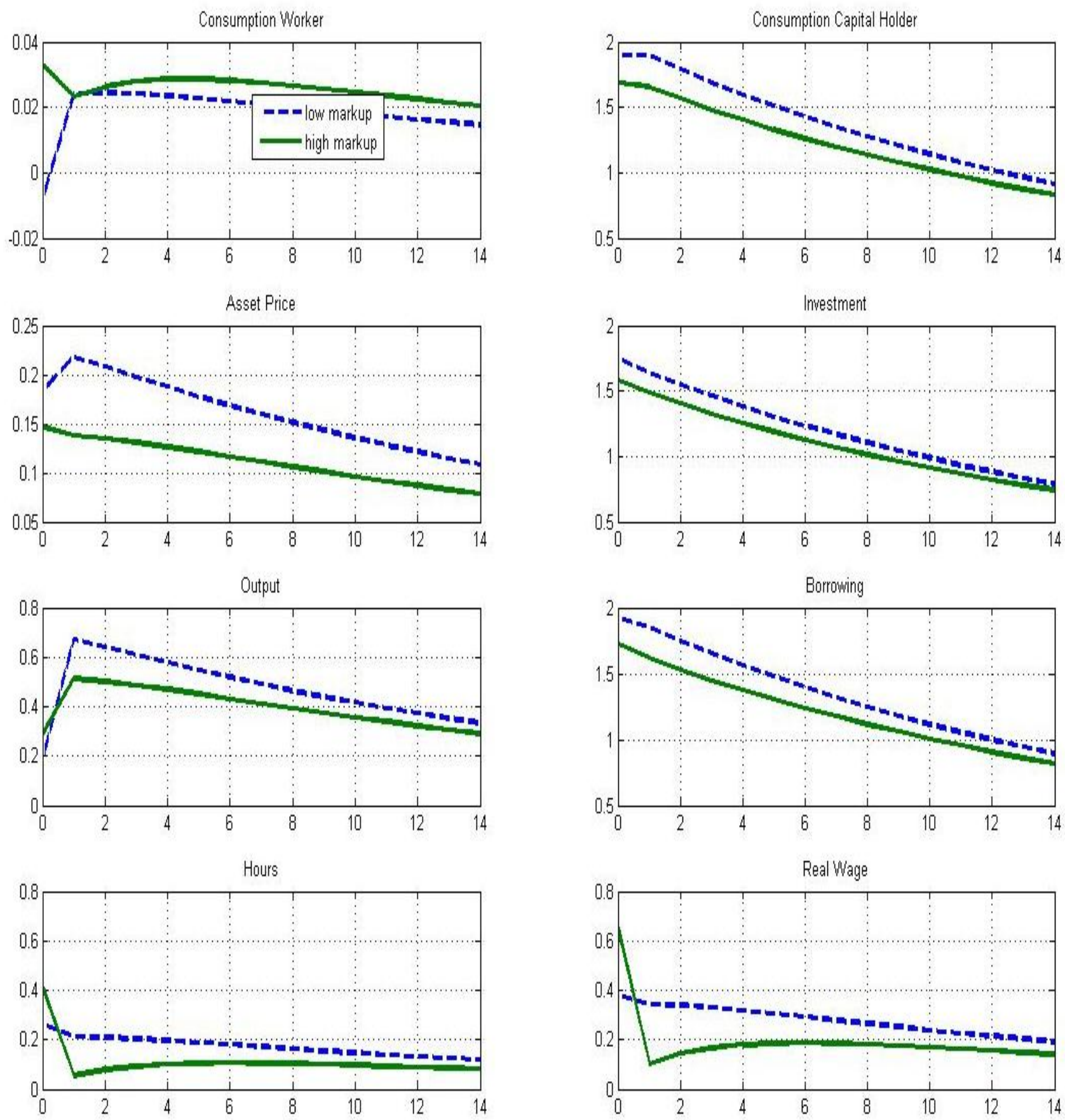
Figure 22. Productivity shock under different degrees of PMR

Extended model: capital owners versus workers
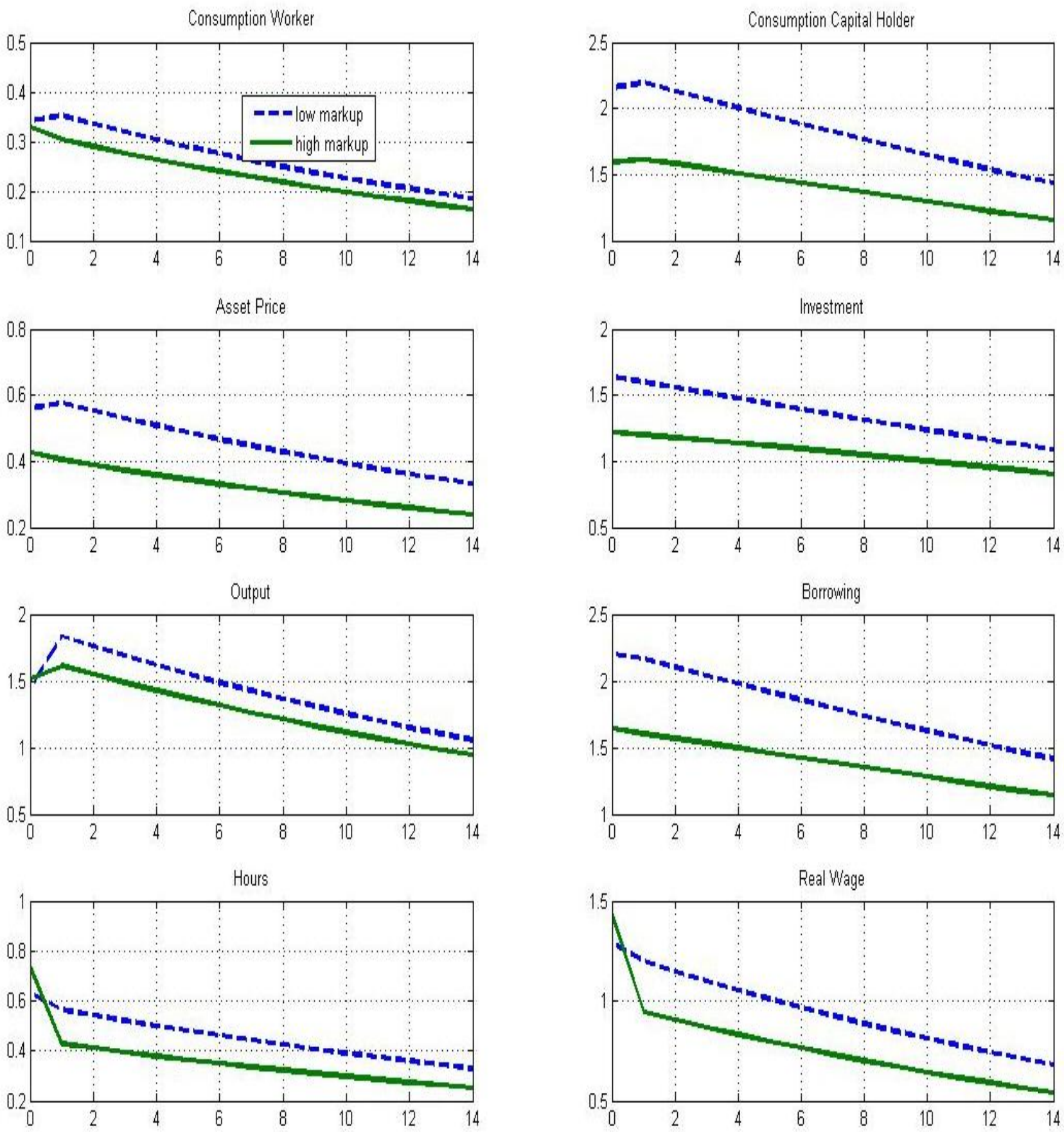
Figure 23. Financial crisis shock under different degrees of wage flexibility

Extended model: capital owners versus workers
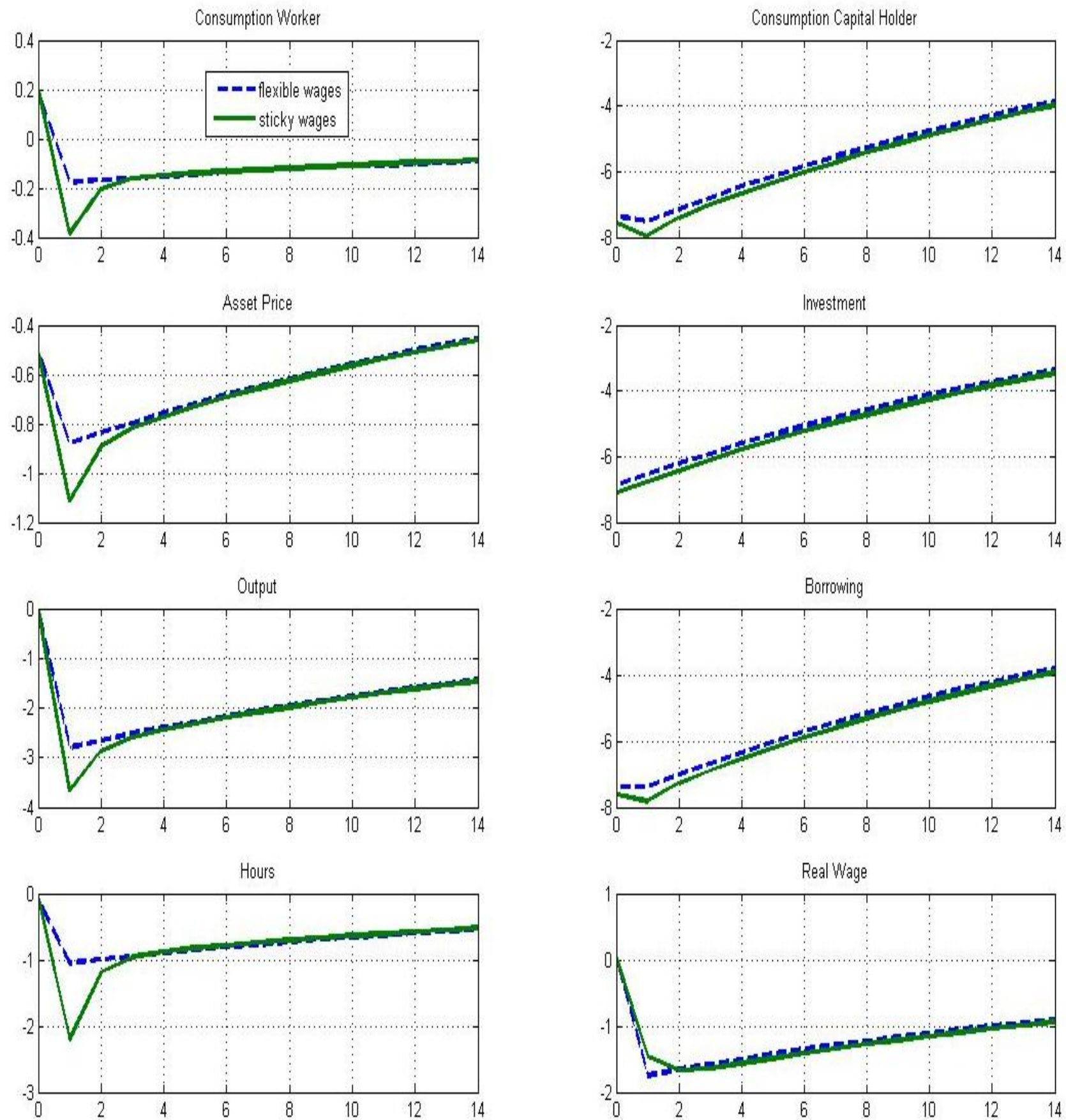
Figure 24. Inflation shock under different degrees of wage flexibility

Extended model: capital owners versus workers

Consumption Worker

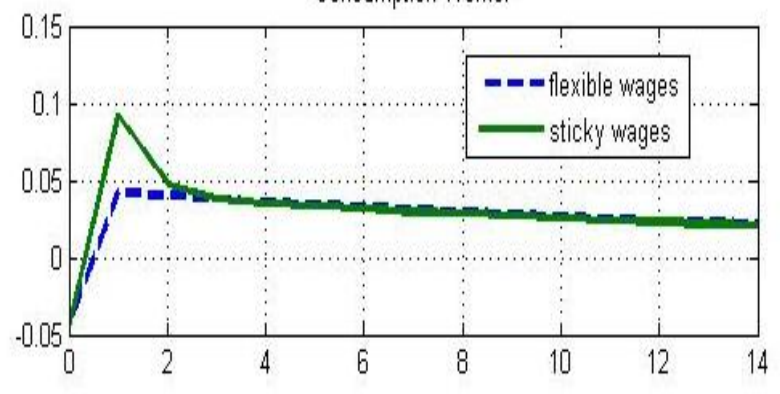

Asset Price



Output
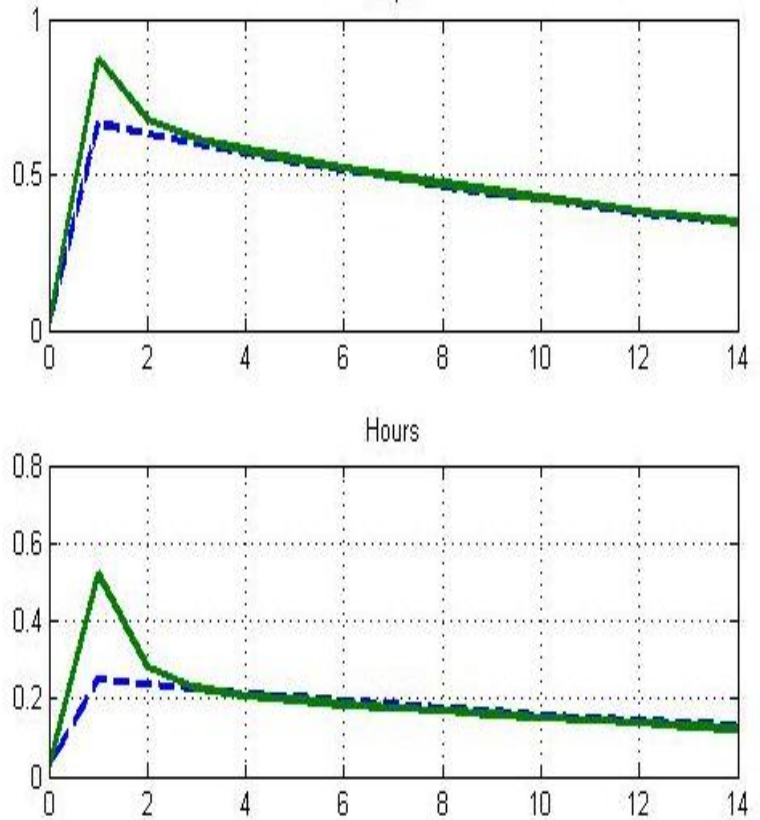

Consumption Capital Holder
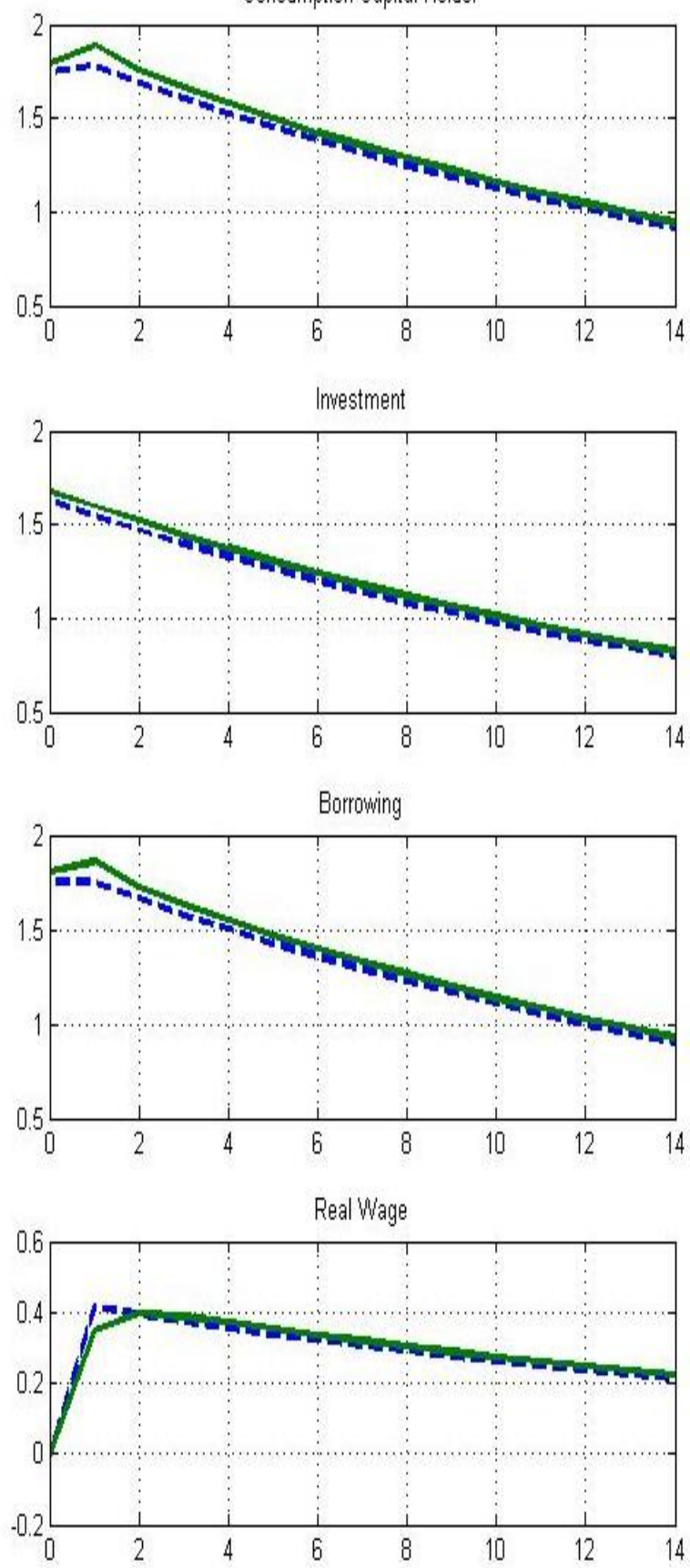
Figure 25. Productivity shock under different degrees of wage flexibility

Extended model: capital owners versus workers

Consumption Worker
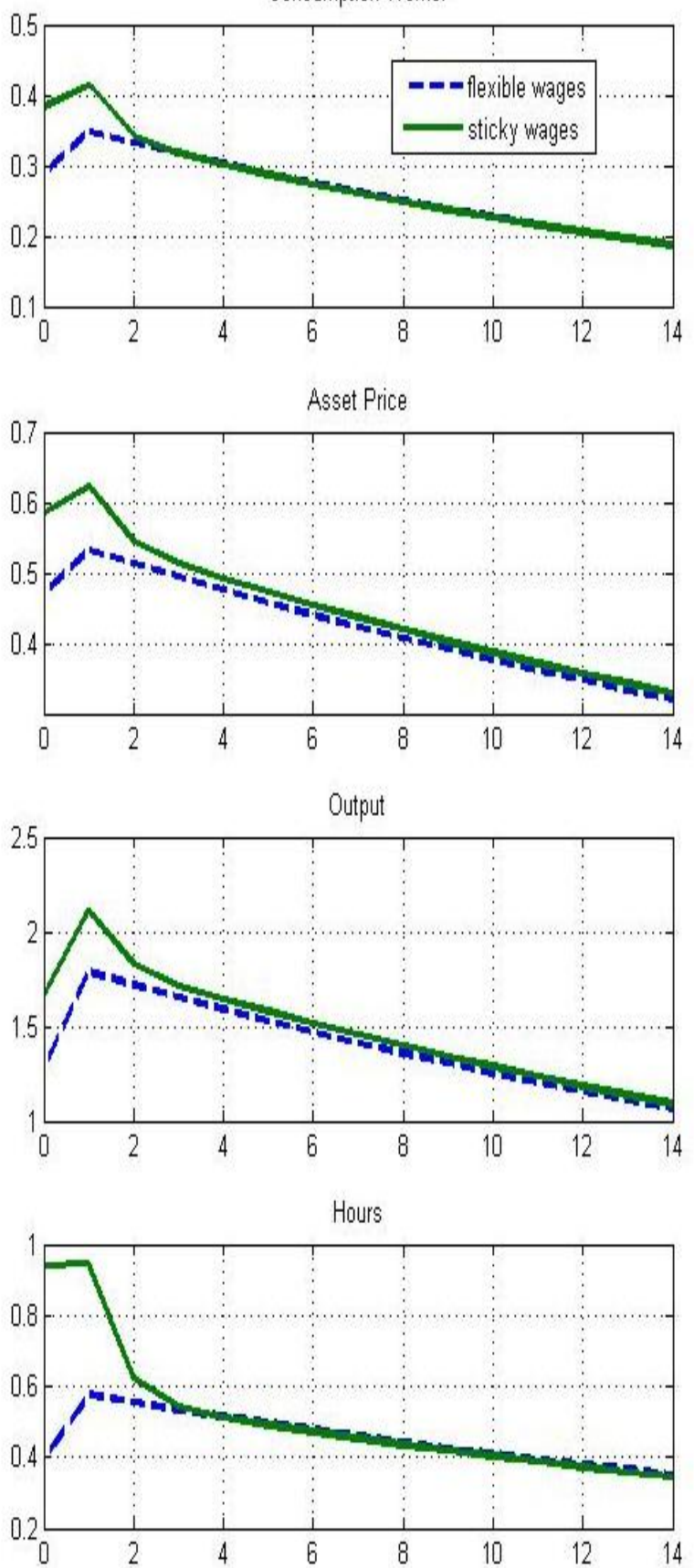

Consumption Capital Holder
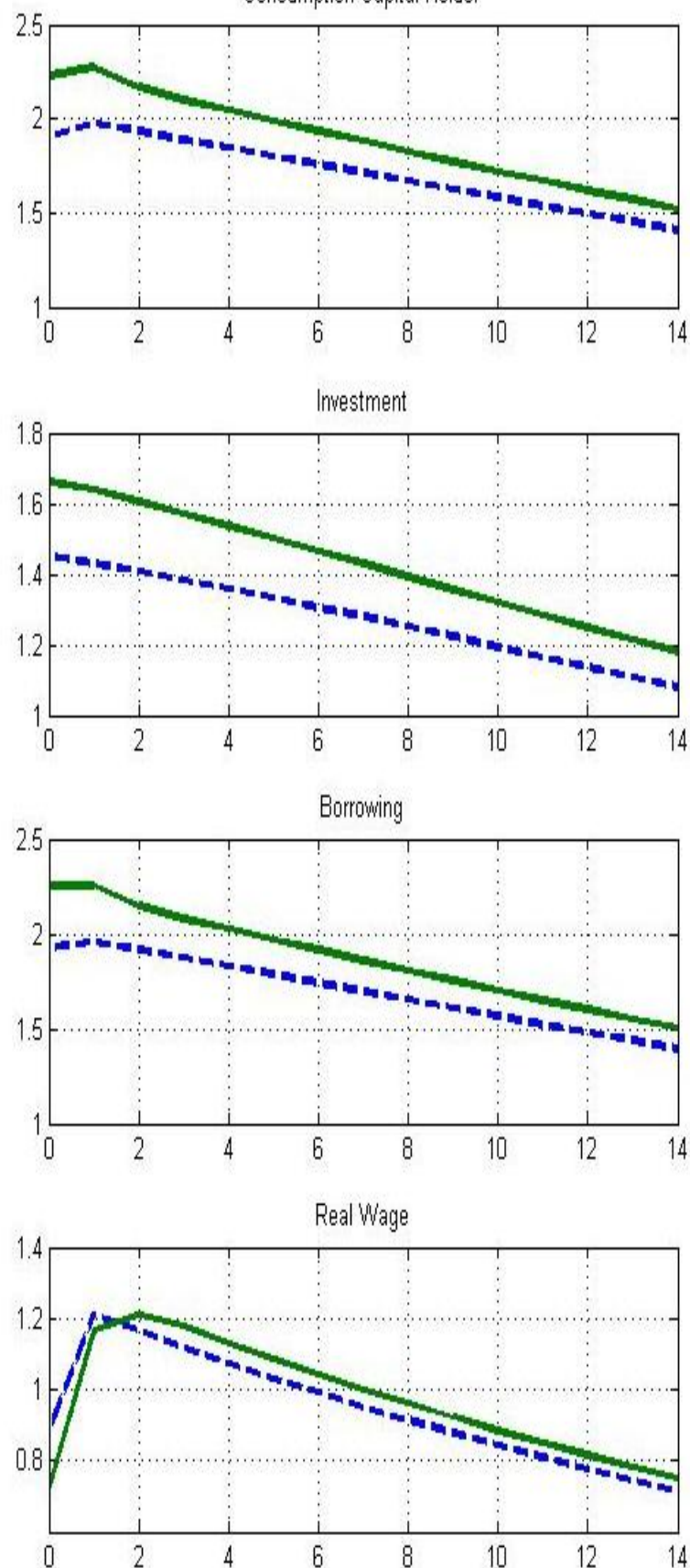


\section{WORKING PAPERS}

The full series of Economics Department Working Papers can be consulted at www.oecd.org/eco/workingpapers/

883. Can India Achieve Double-Digit Growth?

(July 2011) by Richard Herd, Paul Conway, Sam Hill, Vincent Koen and Thomas Chalaux

882. Predicting peaks and troughs in real house prices

(July 2011) by Linda Rousová and Paul van den Noord

881. Public sector spending efficiency in Estonia: healthcare and local government (July 2011) by Zuzana Smidova

880. How to move Product Market Regulation in New Zealand back towards the frontier (July 2011) by Paul Conway

879. Financial sector reform in India: time for a second wave?

(July 2011) by Richard Herd, Vincent Koen, Ila Paitnak and Ajay Shah

878. Policies to rebalance housing markets in New Zealand

(July 2011) by Calista Cheung

877. The sharing of macroeconomic risk: Who loses (and gains) from macroeconomic shocks (July 2011) Rudiger Ahrend, Jens Arnold and Charlotte Moeser

876. Estonia: making the most of globalisation (June 2011) Robert Price and Andreas Wörgötter

875. The effects of downturns on labour force participation: evidence and causes (June 2011) Romain Duval, Mehmet Eris and Davide Furceri

874 A dynamic factor model for world trade growth (June 2011) Stéphanie Guichard and Elena Rusticelli

873. Towards a better understanding of the informal economy (May 2011) Dan Andrews, Aida Caldera Sánchez and Åsa Johansson

872. Tax competition between sub-central governments (May 2011) Hansjörg Blöchliger and José-Maria Pinero-Campos

871. The growth effects of current account reversals: the role of macroeconomic policies (May 2011) Luiz de Mello, Pier Carlo Padoan and Linda Rousová

870. Les politiques du logement en France (May 2011) Bénédicte Rolland

869. How important is wealth for explaining household consumption over the recent crisis? An empirical study for the United States, Japan and the euro area

(May 2011) Clovis Kerdrain 


\section{ECO/WKP(2011)53}

868. Adjusting fiscal balances for asset price cycles

(May 2011) Robert Price and Thai-Thanh Dang

867. Improving the functioning of the housing market in the United Kingdom (May 2011) Christophe André

866. An analysis of demand for foreign exchange reserves

(May 2011) Peter Vujanovic

865. Episodes of large capital inflows and the likelihood of banking and currency crises and sudden stops

(May 2011) Davide Furceri, Stephanie Guichard and Elena Rusticelli

864. The effect of episodes of large capital inflows on domestic credit

(May 2011) Davide Furceri, Stephanie Guichard and Elena Rusticelli

863. Medium-term determinants of international investment positions: the role of structural policies (May 2011) Davide Furceri, Stephanie Guichard and Elena Rusticelli

862. French social housing in an international context (May 2011) Kathleen Scanlon and Christine Whitehead

861. Making the French housing market work better (May 2011) by Hervé Boulhol

860. Surveillance by international institutions: lessons from the global financial and economic crisis (April 2011) by Kumiharu Shigehara and Paul Atkinson

859. France's environmental policies: internalising global and local externalities (April 2011) by Balázs Égert

858. Bringing French public debt down: the options for fiscal consolidation (April 2011) by Balázs Égert

857. Policy frameworks in the post-crisis environment (April 2011) by Nigel Pain and Oliver Röhn

856. Global imbalances, exchange rate pegs and capital flows: a closer look (April 2011) by Paul van den Noord

855 Interest rate pass-through during the global financial crisis: the case of Sweden (April 2011) by Niels-Jakob Harbo Hansen and Peter Welz

854 What drives inflation in the major OECD Economies (April 2011) by Diego Moccero, Shingo Watanabe and Boris Cournède

853 Mitigation potential of removing fossil fuel subsidies: A general equilibrium assessment (April 2011) by J.M. Burniaux and J. Chateau

852 Enhancing labour utilisation in a socially inclusive society in Australia (April 2011) by Vassiliki Koutsogeorgopoulou 